AperTO - Archivio Istituzionale Open Access dell'Università di Torino

\title{
Carnosine-related dipeptides in the mammalian brain.
}

\section{This is the author's manuscript}

Original Citation:

Availability:

This version is available $\mathrm{http}: / /$ hdl.handle.net/2318/22394

since

Published version:

DOI:10.1016/S0301-0082(99)00010-6

Terms of use:

Open Access

Anyone can freely access the full text of works made available as "Open Access". Works made available under a Creative Commons license can be used according to the terms and conditions of said license. Use of all other works requires consent of the right holder (author or publisher) if not exempted from copyright protection by the applicable law. 


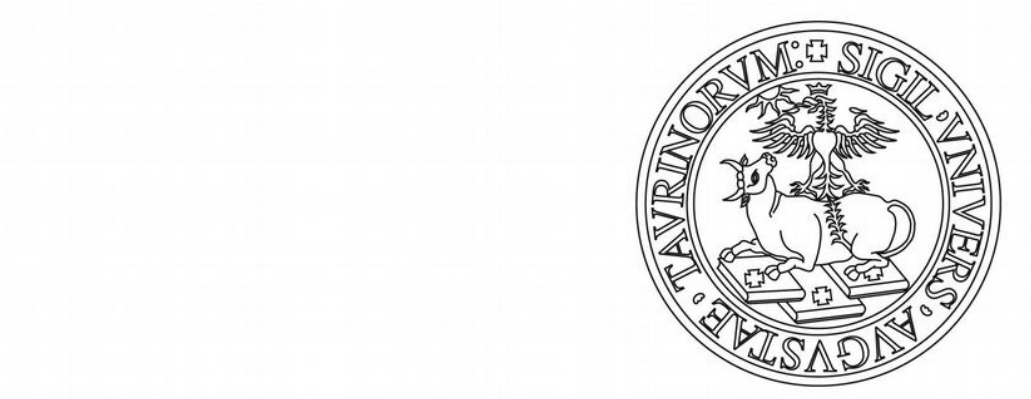

\section{UNIVERSITÀ DEGLI STUDI DI TORINO}

This is an author version of the contribution published on:

Questa è la versione dell'autore dell'opera:

[Prog Neurobiol, 59 (4), 1999, DOI: 10.1016/S0301-0082(99)00010-6]

ovvero [Bonfanti L., Peretto P., De Marchis S., Fasolo A., 59 (4), Elsevier, 1999, pagg.333-353

The definitive version is available at:

La versione definitiva è disponibile alla URL:

[http://www.sciencedirect.com/science/article/pii/S0301008299000106] 
L. BONFANTI ${ }^{*}$, P. PERETTO ${ }^{1 b}$, S. DE MARCHISc and A. FASOLO

a Dipartimento di Morfofisiologia Veterinaria, Via Nizza, 52, 10126, Torino, Italy, ${ }^{b}$ Dipartimento di Morfofisiologia Veterinaria, Università degli Studi di Torino, Torino, Italy, 'Dipartimento di Biologia Animale, Università degli Studi di Torino, Torino, Italy

Abstract - Carnosine and structurally related dipeptides are a group of histidine-containing molecules widely distributed in vertebrate organisms and particularly abundant in muscle and nervous tissue. Although many theories have been proposed, the biological function(s) of these compounds in the nervous system remains enigmatic.

The purpose of this article is to review the distribution of carnosine-related dipeptides in the mammalian brain, with particular reference to some cell populations wherein these molecules have been demonstrated to occur very recently.

The high expression of carnosine in the mammalian olfactory receptor neurons led to infer that this dipeptide could play a role as a neurotransmitter/modulator in olfaction. This prediction, which has not yet been fully demonstrated, does not explain the localization of carnosine-related dipeptides in other cell types, such as glial and ependymal cells.

A recent demonstration of high carnosine-like immunoreactivity in the subependymal layer of rodents, an area of the forebrain which shares with the olfactory neuroepithelium the occurrence of continuous neurogenesis during adulthood, supports the hypothesis that carnosine-related dipeptides could be implicated in some forms of structural plasticity.

However, the particular distribution of these molecules in the subependymal layer, along with their expression in glial/ependymal cell populations, suggests that they are not directly linked to cell migration or cell renewal. In the absence of a unified theory about the role of carnosine-related dipeptides in the nervous system, some common features shared by different cell populations of the mammalian brain which contain these molecules are discussed.

\section{ABBREVIATIONS}

$\begin{array}{ll}\text { AGEs } & \text { advanced glycation endproducts } \\ \text { BrdU } & \text { 5-bromo-2'-deoxyuridine } \\ \text { CNP } & \text { 2'3'-cyclic nucleotide } 3 \text { '-phosphodiesterase } \\ \text { CNS } & \text { central nervous system } \\ \text { GFAP } & \text { glial fibrillary acidic protein } \\ \text { N-CAM } & \text { neural cell adhesion molecule } \\ \text { PSA } & \text { polysialic acid } \\ \text { PSA-NCAM } & \text { polysialylated isoform of N-CAM } \\ \text { SEL } & \text { subependymal layer }\end{array}$

* Corresponding author. Tel.: +39-011-6699853; fax: +39-011-6507754.

${ }^{1}$ Present address: Dipartimento di Biologia Animale, Via Accademia Albertina 13, I-10123 Torino, Italy. 


\section{INTRODUCTION}

\subsection{Carnosine And Carnosine-related Dipeptides}

Carnosine is the archetype of a series of compounds referred to as aminoacylhistidine dipeptides, a group of naturally-occurring histidine-containing molecules which in certain tissues such as muscle represent an appreciable fraction of the water-soluble, non proteic nitrogen-containing compounds. Carnosine ( $\beta$-alanyl-L-histidine) was the first to be described in meat extracts (Gulewitsch and Amiradzibi, 1900) and it has subsequently been found to be widely distributed in animal tissues (Crush, 1970). Some tissues of many vertebrates, including mammals, also contain other aminoacyl-histidine dipeptides: homocarnosine ( $\gamma$-aminobutyryl-L-histidine) and anserine ( $\beta$-alanylL-1-methyl-histidine). $\beta$-alanyl-L-3-methylhistidine has been described in snake and whale muscles, referred to as ophidine (Imamura, 1939) or balenine (Pocchiari et al., 1962) respectively, and other related molecules have been found in mammalian heart (Chrichton et al., 1988).

The dipeptide carnosine is synthesized from its component amino acids $\beta$ alanine and $L$ histidine by the enzyme carnosine synthetase (Winnick and Winnick, 1959; Kalyankar and Meister, 1959; Horinishi et al., 1978). $\beta$-alanine, a constituent of coenzyme $A$, is an unusual aminoacid, absent from proteins; whereas histidine is an essential aminoacid. Carnosine synthetase (EC 6.3.2.11), whose activity is $98 \%$ cytosolic (Harding and O'Fallon, 1979), is an enzyme characterized by a broad substrate specificity, capable of synthesizing different aminoacyl-histidine dipeptides (e.g., carnosine, homocarnosine, anserine; Winnick and Winnick, 1959; Kalyankar and Meister, 1959; Ng and Marshall, 1978; Horinishi et al., 1978). The synthesis has been demonstrated to occur in different tissues, including muscle (Bakardjiev and Bauer, 1994; Bauer and Schulz, 1994) and brain (Horinishi et al., 1978). A carnosinase (EC 3.4.13.3) and an homocarnosinase responsible for the degradation of these compounds have also been identified in different tissues (Rosemberg, 1960; Harding and Margolis, 1976; Lenney, 1976; Lenney et al., 1977; $\mathrm{Ng}$ et al., 1977; $\mathrm{Ng}$ and Marshall, 1978; Harding and O'Fallon, 1979; Margolis et al., 1983; Margolis and Grillo, 1984b).

The aminoacyl-histidine dipeptides are usually abundant in excitable tissues, such as muscle and nervous tissue. Phylogenetically, the aminoacyl-histidine dipeptides are present in vertebrates. Nevertheless, carnosine has been found in some molluscs and arthropods, and the muscles of some low representatives of the fishes do not contain the dipeptides (Crush, 1970). Carnosine and anserine have been found to be simultaneously present in muscles of cat and rabbit. In some species the muscle tissue contains only one type of dipeptide, such as in frog (only carnosine) and in trout (only anserine). Thus, since the occurrence of these molecules (dipeptides, $\beta$-alanine, histidine) in skeletal muscles is highly variable among species (Tamaki et al., 1976), no definitive interpretations are at present available in terms of biochemical evolution. The presence of carnosine has also been reported in many human organs, by using an isocratic reversed phase HPLC assay (Flancbaum et al., 1990). According to other authors, which used immunocytochemical techniques (Jackson and Lenney, 1996), the presence of the dipeptide would be restricted to the skeletal muscle and brain, although this might be linked to a sensitivity problem concerning the detection of this molecule using different techniques. The 
concentration of carnosine in the human skeletal muscle is very high (up to 20 $\mathrm{mM}$ ) in comparison with other mammals, and a correlation between the amount of the dipeptide and the life span of the animals has been proposed (Munch et al., 1997).

The features of aminoacyl-histidine dipeptides as a subset of small molecules which share similarities and which frequently coexist in the same tissue, raises the problem of their specific detection and discrimination using immunological techniques. Two rabbit polyclonal antisera raised against carnosine or anserine have been well characterized in numerous immunocytochemical and biochemical studies (Biffo et al., 1990; Artero et al., 1991a,b; Biffo et al., 1992a,b; Sassoè-Pognetto et al., 1993; Jackson and Lenney, 1996). These antisera were obtained by coupling anserine or carnosine to carrier proteins (Biffo et al., 1990). They can react with protein-conjugated carnosine, homocarnosine and anserine, but not with the free dipeptide haptens or their component aminoacids, including $\beta$-alanine, histidine, $\mathrm{N}$-methylhistidine, GABA or glycine (Biffo et al., 1990). After purification, the anti-carnosine serum still recognizes the three peptide-conjugates, thus preventing the production of monospecific antibodies against carnosine. A similar anti-carnosine serum was first produced by Sakai et al. (1987) and gave the same immunocytochemical pattern in the rat olfactory system. On the other hand, the purified anti-anserine serum does not cross-react immunocytochemically with structures that are immunoreactive for carnosine (Biffo et al., 1990). For the above reasons, the interpretation of the immunocytochemical results obtained with the anti-carnosine serum must be coordinated with detailed biochemical analysis of the tissue under investigation. In this context, the absence of anserine in the nervous system of mammals (see below) allows one to consider the immunoreactivity herein observed as restricted to

carnosine/homocarnosine, referred to as carnosine-like immunoreactivity (-LI), since both these dipeptides have been reported to occur in the mammalian brain. Accordingly, in the present review the aminoacyl-histidine dipeptides carnosine, homocarnosine (and anserine, when speaking of non-mammalian species) will be frequently referred to as carnosine-related dipeptides.

Unfortunately, antibodies raised against the enzyme carnosine synthetase are not useful for immunocytochemistry in mammals (Margolis et al., 1987).

The biological function(s) of the aminoacyl-histidine dipeptides is still open to question, although several theories, often supported by strong experimental data, have been proposed. Numerous studies were carried out in vertebrate skeletal muscles, which contain very high levels of these dipeptides (1-20 mM; Scriver et al., 1983). In the voluntary musculature, during muscle performance, the dipeptides show remarkable buffering properties by neutralizing the largescale formation of lactic acid, thus preventing the decrease of cytosolic $\mathrm{pH}$ (Bate-Smith, 1938; Skulachev, 1978). In addition, several histidine-containing dipeptides display antioxidant properties by preventing the accumulation of oxidized products derived from the lipid peroxidation of biological membranes (Boldyrev et al., 1988; Boldyrev, 1993; Klebanov et al., 1998; for the antioxidant effect of carnosine and other hypothetical roles in the nervous system, see section 4). Other less substantiated hypotheses have also been suggested: some consider these molecules as products of redundant metabolic pathways, which accumulate as a result of degradation of longer polypeptide chains. Such a view is supported by the fact that carnosinase and other related enzymes are less active in muscles in comparison with parenchymatous organs (i.e., kidney), 
in which their activity is very high (Rosemberg, 1960; Lenney, 1976; Margolis and Grillo, 1984b). Finally, it has been reported that carnosine is relatively abundant in histamine rich tissues, such as heart, kidney and stomach, suggesting that this dipeptide can serve as a non-mast cell reservoir for histidine, available for histamine synthesis under physiological stress (Flancbaum et al., 1990).

\section{CARNOSINE-RELATED DIPEPTIDES IN THE NERVOUS SYSTEM}

Carnosine and its congeners homocarnosine and anserine have been found to be abundant in the nervous system of many vertebrates (Table 1). The investigations carried out in different species concerning the localization of these compounds in different areas of the nervous system do not provide an exhaustive picture of their distribution. Most of the studies performed in the past were directed to demonstrate a particular abundance of carnosine-related dipeptides in the olfactory system, in the retina and, to a lesser extent, in the brain. The results of these studies will be briefly summarized here, since the earlier literature on this topic has been reviewed extensively (Crush, 1970; Margolis, 1980; Quinn et al., 1992).

\subsection{Non-mammalian Species}

By examining the distribution of carnosine-related dipeptides in the nervous system of non-mammalian species important differences have been described as concerns the occurrence of different dipeptides and their regional localization (Table 1).

In the nervous system of birds, both anserine and carnosine are present, the former associated with glial cells in the brain, the latter restricted to the olfactory receptor neurons (Biffo et al., 1990). Thus, anserine is the only dipeptide detectable in the avian central nervous system (CNS), apart from the olfactory neuron axonal projections in the olfactory bulb, which contain carnosine. High levels of anserine have also been detected in the avian retina (Margolis and Grillo, 1984a), where the dipeptide is thought to be localized in Muller glial cells.Anserine is not detectable in the brain tissue of non-avian species (Wideman et al., 1978; Bauer et al., 1979,1982; Nadi and Margolis, 1978). Biochemical analysis carried out in the nervous system of amphibia and reptilia demostrated that primarily homocarnosine and to a lesser extent carnosine are present (Artero et al., 1991a). In reptiles these peptides are detectable in the olfactory pathway, associated with the olfactory receptor neurons, whereas in amphibians they are absent from this cell population (Artero et al., 1991a,b).

As to the cellular localization of carnosine-related dipeptides in the CNS of these species, immunocytochemical studies showed that in reptiles they are present in glial cells, whereas in amphibians striking differences were found among certain anuran and urodele species: in the former (Rana esculenta and Xenopus laevis) the dipeptides are present in glial cells, whereas in the latter (crested newt, Triturus carnifex) they have been observed to occur in several nerve cell populations (Artero et al., 1991a,b). Interestingly, in the crested newt, despite their occurrence in brain neurons, the aminoacyl-histidine dipeptides are undetectable in olfactory receptors.

As to the cellular localization of carnosine synthetase, due to a lack of antibodies capable of recognizing this enzyme in situ, the frog olfactory system 
is, to date, the only neural tissue in which an immunoreactivity for carnosine synthetase has been detected, where it appears to be restricted to a subpopulation of the olfactory receptor neurons (Crowe and Pixley, 1991). In frogs, carnosine-LI has been also shown to occur in retinal neurons (SassoèPognetto et al., 1992; Panzanelli et al., 1997) and in hair cells of the semicircular canals of the inner ear (Panzanelli et al., 1994). In the frog retina, primarily carnosine has been detected, localized in virtually all photoreceptors and bipolar cells. An immunoreactivity has also been described in some presumed amacrine and ganglion cells, as well as in Muller cells endfeet (Panzanelli et al., 1997). In the sensory epithelium of the ampullary cristae, carnosine-LI has been found to be restricted to the receptor cells (hair cells), being absent in the supporting cells, and to the fibers of the vestibular nerve (Panzanelli et al., 1994). Also in other species, these molecules are preferentially localized in sensory cells, including those of the lateral line organ of Xenopus (Mroz and Sewell, 1989) or the saccular nerve of the trout (Drescher and Drescher, 1991).

Table 1. Distribution of carnosine-related dipeptides in the nervous system

\begin{tabular}{|c|c|c|c|c|}
\hline Dipeptides & Classes & Localization & Remarks & References \\
\hline \multicolumn{5}{|l|}{ Non-mammalia } \\
\hline \multirow[t]{7}{*}{ Carnosine } & Osteichthyes & Saccular nerve & B & Drescher and Drescher, 1991 \\
\hline & Amphibia Anura & Brain & $\mathrm{B}$ & $\begin{array}{l}\text { Margolis and Grillo 1984a; } \\
\text { Artero et al., 1991a }\end{array}$ \\
\hline & & Retina & B & Margolis and Grillo, 1984a \\
\hline & & Lateral line organ & B & Mroz and Sewell, 1989 \\
\hline & Reptilia & Brain & B & Artero et al., 1991a \\
\hline & Aves & Olfactory bulb & B & $\begin{array}{l}\text { Fisher et al., 1977; } \\
\text { Margolis and Grillo,1984a }\end{array}$ \\
\hline & & Retina & B & Margolis and Grillo, 1984a \\
\hline \multirow[t]{4}{*}{ Homocarnosine } & Osteichthyes & Brain, Retina & $\mathrm{B}$ & Margolis and Grillo, 1984a \\
\hline & Amphibia Anura & Brain & B & $\begin{array}{l}\text { Yockey and Marshall, } 1969 \\
\text { Margolis and Grillo, 1984a; } \\
\text { Artero et al., 199la }\end{array}$ \\
\hline & Reptilia & Brain & B & Artero et al., 1991a \\
\hline & Aves & Brain & B & Kanazawa and Sano, 1967 \\
\hline \multirow[t]{2}{*}{ Anserine } & Aves & Brain $\left(\right.$ glia $\left.^{1}\right)$ & $\mathrm{B}, \mathrm{ICC}^{1}$ & $\begin{array}{l}\text { Tsunoo et al., 1963a; } \\
\text { Fisher et al., } 1977 \\
\text { Margolis and Grillo, 1984a; } \\
\text { Biffo et al., } 1990^{1}\end{array}$ \\
\hline & & Retina & B & $\begin{array}{l}\text { Tsunoo et al., 1963b; } \\
\text { Margolis and Grillo, 1984a }\end{array}$ \\
\hline \multirow[t]{6}{*}{ Carnosine-like } & Amphibia Anura & Brain (glia) & ICC & Artero et al., 1991a \\
\hline & & Retina (neurons) & ICC & $\begin{array}{l}\text { Sassoè-Pognetto et al., 1992; } \\
\text { Panzanelli et al., } 1997\end{array}$ \\
\hline & & $\begin{array}{l}\text { Vestibular system } \\
\text { (sensory receptors) }\end{array}$ & ICC & Panzanelli et al., 1994 \\
\hline & Amphibia Urodela & Brain (neurons) & $\mathrm{ICC}$ & Artero et al., 1991b \\
\hline & Reptilia & Brain (glia) & ICC & Artero et al., 1991a \\
\hline & Aves & $\begin{array}{l}\text { Olfactory epithelium } \\
\text { (neurons) }\end{array}$ & $\mathrm{ICC}$ & Biffo et al., 1990 \\
\hline
\end{tabular}




\begin{tabular}{|c|c|c|c|c|}
\hline Dipeptides & Species & Localization & Remarks & References \\
\hline \multicolumn{5}{|l|}{ Mammalia } \\
\hline \multirow[t]{10}{*}{ Carnosine } & \multirow[t]{3}{*}{ Mouse } & Brain & B, low & Neidle and Kandera, 1974 \\
\hline & & $\begin{array}{l}\text { Olfactory bulb/ } \\
\text { epithelium }^{1}\end{array}$ & B, high & $\begin{array}{l}\text { Margolis, } 1974^{1} \text {; } \\
\text { Neidle and Kandera 1974; } \\
\text { Ferriero and Margolis, } \\
1975^{1} \text {; }\end{array}$ \\
\hline & & & & Wideman et al., 1978 \\
\hline & \multirow[t]{2}{*}{ Rat } & Brain & $\mathrm{B}$, low & $\begin{array}{l}\text { Ferriero and Margolis, 1975, } \\
\text { Quinn and Fisher, 1977; } \\
\text { Ng and Marshall, 1978; } \\
\text { Cairns et al. 1988; } \\
\text { O'Dowd et al., 1990 }\end{array}$ \\
\hline & & $\begin{array}{l}\text { Olfactory bulb/ } \\
\text { epithelium }^{1}\end{array}$ & B, high & $\begin{array}{l}\text { Ferriero and Margolis } 1975^{1} \text {; } \\
\text { Quinn and Fisher 1977; } \\
\text { Margolis and Grillo } 1977^{1}\end{array}$ \\
\hline & Hamster & $\begin{array}{l}\text { Olfactory bulb/ } \\
\text { epithelium }{ }^{1}\end{array}$ & $\mathrm{~A}, \mathrm{~B}$ & $\begin{array}{l}\text { Margolis, } 1980 \\
\text { Burd et al., } 1982^{1}\end{array}$ \\
\hline & Rabbit & Olfactory bulb & B & Margolis, 1980 \\
\hline & Dog & Olfactory bulb & B & $\begin{array}{l}\text { Margolis, 1980; } \\
\text { Nadi et al., } 1980\end{array}$ \\
\hline & Pig & Olfactory bulb & B & Margolis, 1980 \\
\hline & Human & Brain/Olfactory bulb & B & Kish et al., 1979 \\
\hline \multirow[t]{10}{*}{ Homocarnosine } & \multirow[t]{3}{*}{ Mouse } & Brain & B & $\begin{array}{l}\text { Neidle and Kandera, 1974; } \\
\text { Ferriero and Margolis, } 1975\end{array}$ \\
\hline & & Olfactory bulb & $\mathrm{B}$, low & $\begin{array}{l}\text { Neidle and Kandera, 1974; } \\
\text { Ferriero and Margolis, } 1975\end{array}$ \\
\hline & & Retina & $\mathrm{B}$, low & Margolis and Grillo, 1984a \\
\hline & \multirow[t]{2}{*}{ Rat } & Brain & B & $\begin{array}{l}\text { Kanazawa and Sano, 1967; } \\
\text { Ferriero and Margolis, 1975; } \\
\text { Quinn and Fisher, 1977; } \\
\text { Cairns et al., 1988; } \\
\text { O'Dowd et al., 1990 }\end{array}$ \\
\hline & & Retina & $\mathrm{B}$, low & Margolis and Grillo, 1984a \\
\hline & Guinea Pig & Brain & B & $\begin{array}{l}\text { Abraham et al., 1964; } \\
\text { Kanazawa and Sano, } 1967\end{array}$ \\
\hline & Rabbit & Brain & B & Kanazawa and Sano, 1967 \\
\hline & Bovin & Brain & B & Pisano et al., 1961 \\
\hline & Monkey & Brain & $\mathrm{B}$ & $\begin{array}{l}\text { Enwonuwu and } \\
\text { Worthington, } 1974\end{array}$ \\
\hline & Human & Brain & $\mathrm{B}$ & $\begin{array}{l}\text { Abraham et al., 1962; } \\
\text { Kanazawa and Sano, 1967; } \\
\text { Kish et al., } 1979\end{array}$ \\
\hline \multirow[t]{6}{*}{ Carnosine-like } & \multirow[t]{2}{*}{ Mouse } & Brain (glia, $\mathrm{SEL}^{2}$ ) & ICC & $\begin{array}{l}\text { Biffo et al., 1990; } \\
\text { Peret to et al., } 1998^{2}\end{array}$ \\
\hline & & $\begin{array}{l}\text { Olfactory epithelium } \\
\text { (neurons) }\end{array}$ & $\mathrm{ICC}$ & Biffo et al., 1990 \\
\hline & \multirow[t]{2}{*}{ Rat } & Brain (glia, SEL ${ }^{2}$ ) & $\mathrm{ICC}$ & $\begin{array}{l}\text { Biffo et al., 1990; } \\
\text { De Marchis et al., 1997; } \\
\text { Peretto et al., } 1998^{2}\end{array}$ \\
\hline & & $\begin{array}{l}\text { Olfactory epithelium } \\
\text { (neurons) }\end{array}$ & ICC & $\begin{array}{l}\text { Sakai et al., } 1987 \\
\text { Sakai et al., 1988; } \\
\text { Biffo et al., } 1990\end{array}$ \\
\hline & \multirow[t]{2}{*}{ Human } & Brain & ICC & Jackson and Lenney, 1996 \\
\hline & & $\begin{array}{l}\text { Olfactory epithelium } \\
\text { (neurons) }\end{array}$ & ICC & Sakai et al., 1990 \\
\hline
\end{tabular}




\subsection{Mammals}

A number of studies employing various analytical methods established that anserine is absent in the mammalian nervous system, which only contains homocarnosine and carnosine (Nadi and Margolis, 1978; Wideman et al., 1978; Bauer et al., 1979,1982; Margolis and Grillo, 1984a; Biffo et al., 1990) (Table 1). Although previous observations suggested that homocarnosine was the prevalent aminoacylhistidine dipeptide in the brain (Sano, 1965), further studies demonstrated the occurrence of high amounts of carnosine $(2 \mathrm{~nm} / \mathrm{mg}$ of tissue) in the olfactory mucosa and olfactory bulb of rodents (Margolis, 1974; Wideman et al., 1978), whereas lower concentrations of the dipeptide are detectable in the brain $(0.01-0.2 \mathrm{~nm} / \mathrm{mg})$, in association with homocarnosine (Pisano et al., 1961; Abraham et al., 1962; Margolis, 1974; Cairns et al., 1988). Low levels of homocarnosine are also present in the mammalian retina (Margolis and Grillo, 1984a).

Earlier immunocytochemical studies, which were aimed to establish the cellular localization of the carnosine-related dipeptides in the nervous system of adult mammals, revealed a distribution similar to that described in reptiles (or that described for anserine in birds), involving both neurons and glial cells (Biffo et al., 1990). The neuronal localization was restricted to a cell population which is located outside the brain, the olfactory receptor neurons, whereas in the brain carnosine-LI was mainly associated with a population of glial-like cells scattered within both the white and grey matter, to ependymal cells and to a particular type of astrocytic cells in the cerebellum known as Bergmann glia (Biffo et al., 1990). However, more recent studies revealed a more complex distribution of these dipeptides in the mammalian brain, which will be described in detail in section 3.

\subsubsection{Carnosine-related Dipeptides In The Olfactory System}

The presence of high amounts of carnosine in the olfactory system has been widely confermed using autoradiographic (Burd et al., 1982), biochemical (Margolis, 1974; Burd et al., 1982) and immunocytochemical (Schwob and Gottlieb, 1986; Sakai et al., 1987; Biffo et al., 1990) methods. The olfactory receptor neurons abundantly contain carnosine in their perikaria and cell processes, including the axonal projections to the main and accessory olfactory bulb (Biffo et al., 1990) (Figs. 1,2). These olfactory fibers reach the glomerular layer of the olfactory bulb and contain the dipeptide in their synaptic terminals (Sakai et al., 1988; Sassoè-Pognetto et al., 1993). In studies carried out after peripheral deafferentation, it appeared evident that they are responsible for the high concentration of carnosine in the olfactory bulb, in comparison with the rest of the brain (Margolis, 1974; Neidle and Kandera, 1974; Ferriero and Margolis, 1975; Nadi et al., 1980). Indeed, following irrigation of the mucosa with radiolabelled $\beta$-alanine and histidine, the precursors are rapidly taken up and converted in carnosine, which is transported to the olfactory bulb by axonal flow (Margolis and Grillo, 1977).

The human brain contains high concentrations of homocarnosine (Kanazawa and Sano, 1967) and little or no carnosine, except for the olfactory bulb (Kish et al., 1979). Carnosine-LI has been detected in olfactory receptor neurons of the human olfactory mucosa, with a cellular distribution similar to that described in rodents (Sakai et al., 1990). This suggests that carnosine could be primarily 


\subsection{Conclusions}

The cellular distribution of carnosine-related dipeptides in the nervous system is similar in reptiles, birds and mammals, although differences are present about the type of dipeptide(s) found in each class. Some differences in the anatomical distribution of these molecules were observed in amphibians, primarily concerning their absence in the olfactory system and, at least in urodeles, their presence in neuronal cell populations of the CNS. On the whole, earlier studies led to the general assumption that in the nervous system of vertebrates carnosine-related dipeptides are preferentially expressed in sensory organs. In spite of important differences observed in the distribution of these molecules in phylogenetically different vertebrate species, they are detectable in a wide range of sensory cell types. As discussed below, such a distribution suggested a possible role for carnosine as a neuromodulator, at least within some of these sensory systems. Nevertheless, the presence of carnosine-related molecules in numerous non-neuronal cell types in the brain, leaves open several hypotheses about its function.

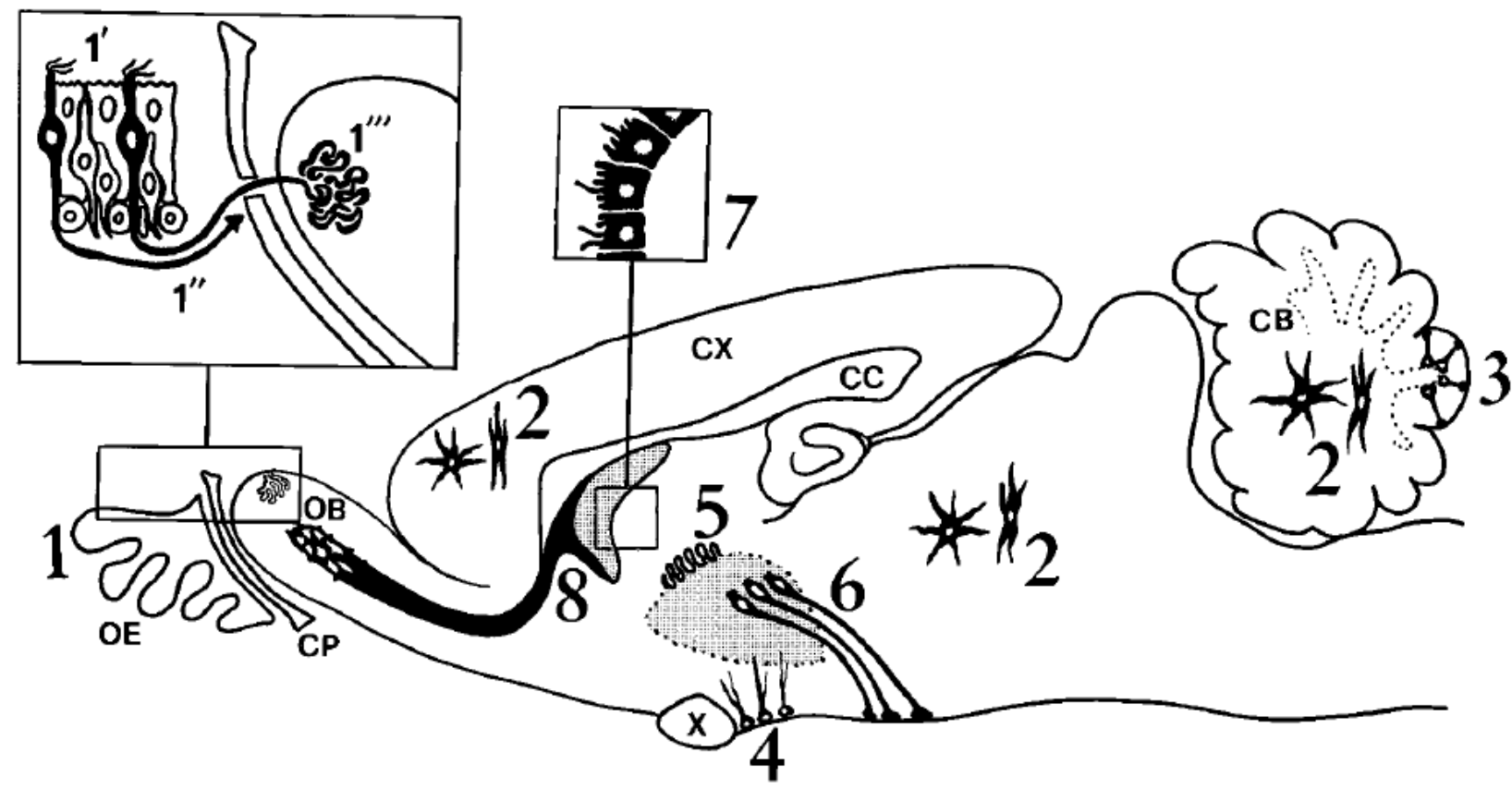

Fig. 1. Schematic representation of the distribution of carnosine and carnosine-related dipeptides in the adult mammalian brain and olfactory system. 1, In the olfactory system, carnosine-LI is present in the mature olfactory receptor neurons $\left(1^{\prime}\right.$, in black) of the olfactory epithelium (OE), in their axons (1") which project to the olfactory bulb (OB) crossing the cribriform plate (CP), and in the olfactory glomeruli (1'"'), which correspond to the terminations of these axons in the glomerular layer. 2, Subpopulations of astrocytes and oligodendrocytes scattered throughout the grey and white matter (here represented schematically in the cerebral cortex (CX), brain stem and cerebellum (CB). 3, Bergmann glial cells, a remnant of embryonic radial glia persisting as elongated, radially oriented elements in the cerebellar cortex (the dotted line marks the limit between the granule cell layer and the molecular layer). 4, radial glia-like cells of the hypothalamic supraoptic nucleus. 5, Subfornical organ. 6 , Tanycytes. 7, Ependymal cells of the ventricular cavities (here represented in the wall of the lateral ventricle). 8, Subependymal layer (SEL); more details on the distribution of carnosine-LI in this region are given in Fig. 9. CC, corpus callosum; X, optic chiasm. The lateral ventricle and the third ventricle (the perimeter of this latter marked with a dotted line) are indicated by the dotted areas. 


\section{DISTRIBUTION OF CARNOSINE-RELATED DIPEPTIDES IN THE MAMMALIAN BRAIN}

The studies reported above, up to date until the 90s, led to the assumption that, in mammals, carnosine-related dipeptides are present in two distinct cell populations of the nervous system: one neuronal (the olfactory receptor neurons), located outside the brain, the other glial and widespread within the brain. Further studies carried out in the last decade have investigated in more detail the distribution of carnosine in different glial cell types, and characterized its synthesis and uptake in vitro. Moreover, these molecules have been demonstrated to occur within an area of the adult forebrain (the subependymal layer) which has been recently proposed as a site of active neurogenesis.

\subsection{Carnosine-related Dipeptides In Glial Cells}

Apart from the olfactory axonal projections to the olfactory bulb and the undifferentiated cells of the subependymal layer (SEL), which are considered as neuronal precursors (see section 3.2), in the rest of the mammalian brain carnosine-related dipeptides have been found exclusively in glial and ependymal cells, but not in mature neurons (Fig. 1).

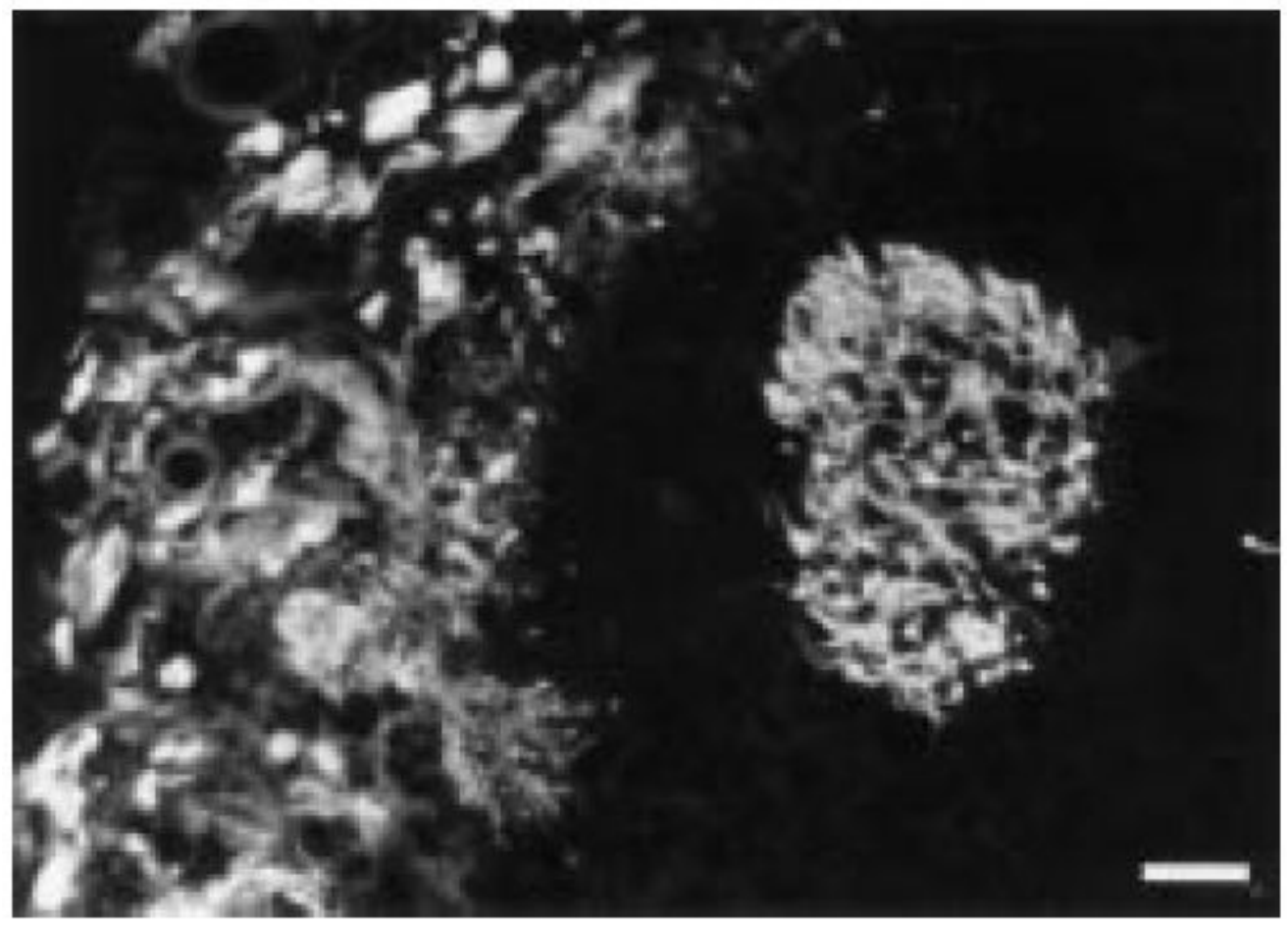

Fig. 2. Carnosine-LI in the main olfactory bulb of the adult rabbit. The immunoreactivity is localized in the olfactory nerve layer (left), corresponding to the axonal projections of the olfactory receptor neurons, and in their terminations forming a glomerulus (right). Calibration bar: $30 \mu \mathrm{m}$.

In recent studies carried out in vivo on the brain of adult rats (De Marchis et al., 1997 ) it has been pointed out that the carnosine-LI 'glial-like" cells frequently fall into two different morphological types: stellate-shaped, process-bearing cells, reminiscent of the astrocytic morphology, and round-shaped cells with apparently unstained processes. By using double labelling techniques with glial 
markers, it has been shown that the process-bearing cells actually are astrocytes (Fig. 4A and B), whereas the round-shaped cells are GFAP-negative, 2'3'-cyclic nucleotide 3'-phosphodiesterase (CNP)-positive oligodendrocytes (Fig. 4C and D).

On the other hand, in vitro experiments carried out on primary cultures of mixed glia or cultures selectively enriched in astrocytes and oligodendrocytes, revealed the presence of carnosine in oligodendrocytes only (De Marchis et al., 1997; Fig. 5).Moreover, in the enriched cultures, which contain oligodendrocytes at different maturation stages, only a small subset of cells were immunoreactive. The same cells appeared immunostained with markers of mature oligodendrocytes such as CNP and myelin basic protein, but not with markers specific for oligodendrocyte precursors, thus suggesting that only completely differentiated oligodendroglia cells actually contain carnosinerelated dipeptides. These results are in accord with in vivo studies demonstrating that the dipeptides are not present in all glial cells (Fig. 4), but are restricted to subpopulations of mature astrocytes and oligodendrocytes (Biffo et al., 1990; De Marchis et al., 1997).

Among astrocytes, carnosine-LI is highly expressed in typical stellate-shaped cells, in the glial coverage of blood vessels formed by their processes, and in certain cell populations which are remnants of radial glia, such as the cerebellar Bergmann glia (Biffo et al., 1990), or display a radial glial-like morphology such as certain glial cells in the hypothalamic supraoptic nuclei (not shown; see Fig. 1).

Other highly carnosine-LI cell populations which are classified among glial cells are ependymal cells and tanycytes (Fig. 3B). These cells line the ventricular cavities forming a barrier between the cerebrospinal fluid and the neuropil, and play an active role in the regulation of the exchanges between these compartments (Bruni, 1998). Tanycytes are considered a particular type of glial/ependymal cells (Bascò et al., 1981; de Vitry et al., 1981) which line certain parts of the ventricular cavities, being most abundant in the ventrolateral wall of the third ventricle. These cells contact the ventricular lumen and send a long process reminiscent of embryonic radial glia in the surrounding neuropil (Flament-Durand and Brion, 1985). Finally, strong carnosine- $\mathrm{LI}$ is detectable in the subfornical organ (Fig. 3A), a midline sagittal structure protruding in the lumen of the third ventricle and enriched in ependymal cells, glial cells and tanycytes (Dellmann, 1998). 

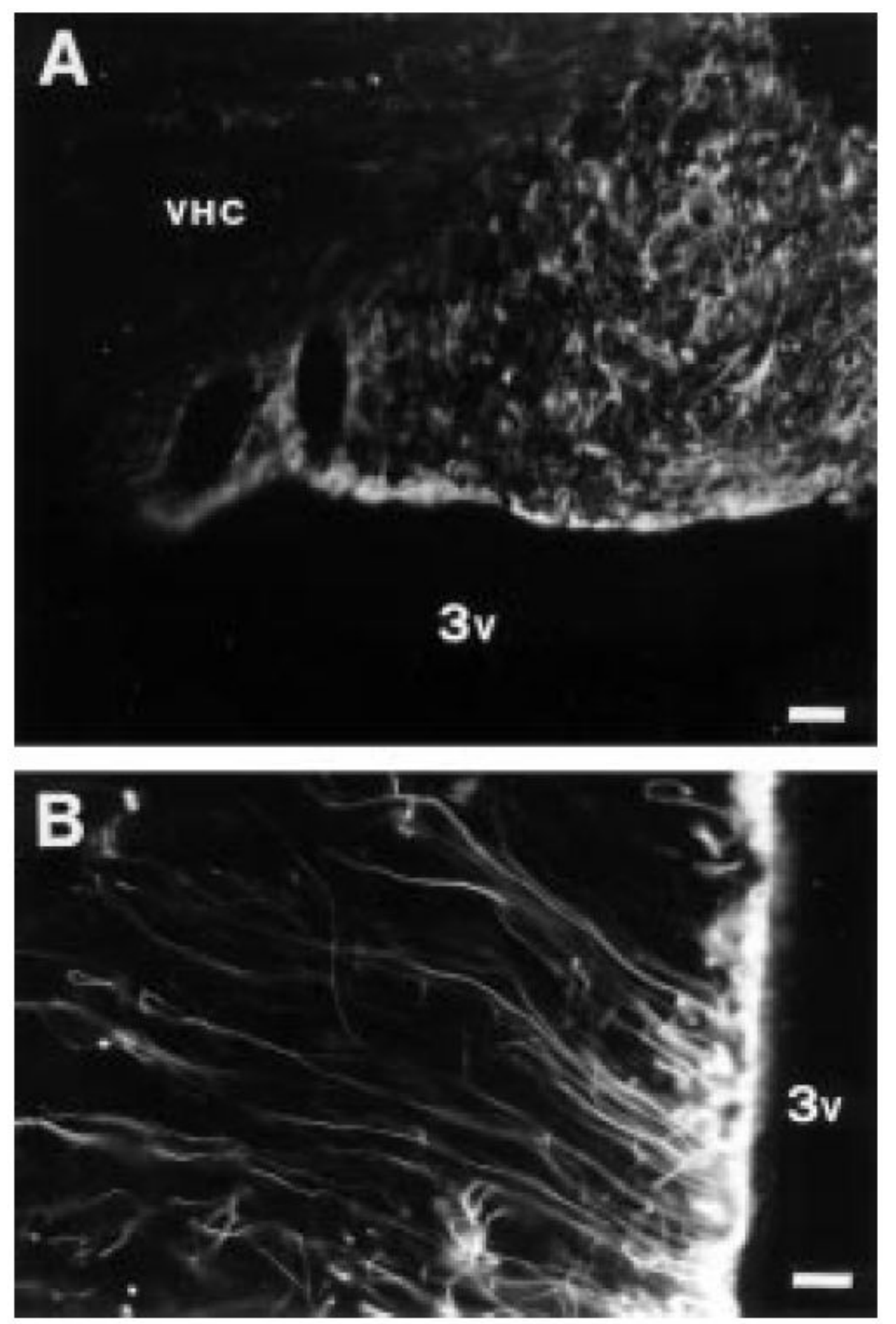

Fig. 3. Carnosine-LI in the subfornical organ (A) and in tanycytes (B) surrounding the third ventricle $(3 \mathrm{v})$ of the adult rat. VHC, ventral hippocampal commissure. Calibration bars: $A, 50$ $\mathrm{mm} ; \mathrm{B}, 30 \mu \mathrm{m}$. 

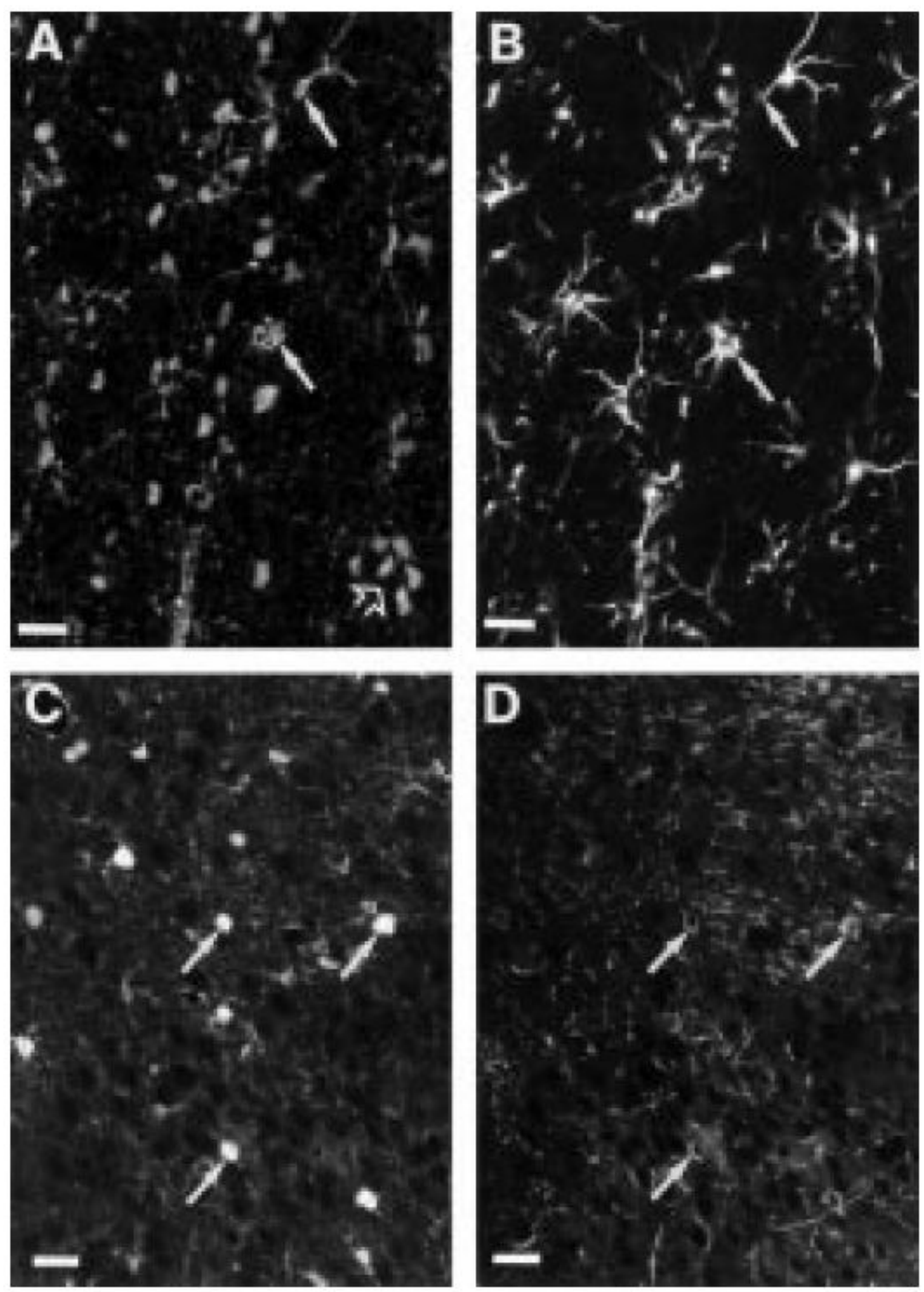

Fig. 4. Carnosine-LI in glial cells of the adult mammalian brain. A,B, Double labelling for carnosine (A) and GFAP (B) in the olfactory tubercle. The immunoreactivity for carnosine is visible in a sub-population of astrocytes (two are indicated by arrows), and in other cells types which do not contain GFAP (six are indicated by the open arrow). C,D, Double labelling for carnosine (C) and CNP (D) in the brainstem. Numerous mature oligodendrocytes (some of which are indicated by arrows) are carnosine-LI. Calibration bars: $30 \mu \mathrm{m}$. 

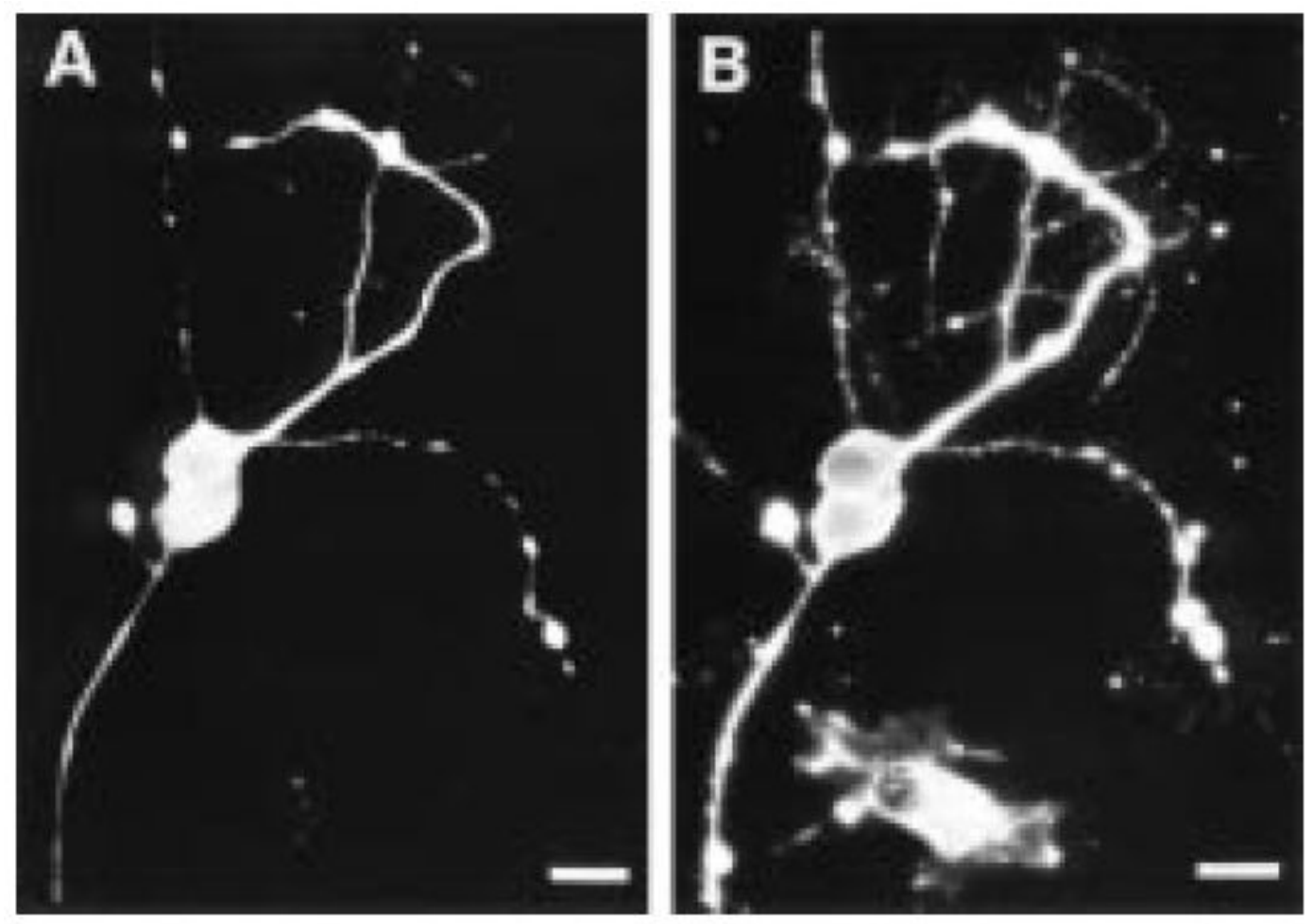

Fig. 5. Oligodendrocytes enriched cultures from the rat brain. Double labelling for carnosine (A) and myelin basic protein (B) in mature oligodendrocytes. Calibration bars: $20 \mu \mathrm{m}$.

\subsubsection{Carnosine Synthesis And Uptake}

The enzyme carnosine synthetase was purified from chicken pectoral muscle (Winnick and Winnick, 1959; Kalyankar and Meister, 1959), mouse olfactory bulb (Horinishi et al., 1978) and whole rat brain (Skaper et al., 1973). Although considered an enzyme with broad substrate specificity, the mouse olfactory carnosine synthetase is clearly different from the chicken enzyme (called carnosine-anserine synthetase) in terms of specificity. It seems uncapable of anserine synthesis, whereas it can synthesize homocarnosine (Horinishi et al., 1978). Monoclonal antibodies raised against this enzyme (Margolis et al., 1987) have been useful in characterizing immunological similarities across mammalian species but have not been helpful in resolving the cellular localization of carnosine synthetase activity, therefore its distribution has been investigated in biochemical and in vitro studies.

In the olfactory mucosa of rodents, carnosine synthesis has been demonstrated to occur starting from embryonic day 16 (Margolis et al., 1985). Several lines of evidence suggest that carnosine synthetase is not saturated with its substrate in physiological conditions and that the immediate precursor $\beta$-alanine may play a role in regulating tissue carnosine levels (Margolis et al., 1985). In cell cultures, biosynthesis of carnosine has been demonstrated to occur in muscle cells and in glial cells (Bauer et al., 1982; Bakardjiev and Bauer, 1994; Hoffmann et al., 1996; Bakardjiev, 1997). By contrast, no significant synthesis of homocarnosine was described, probably due to the fact that glial cells rapidly degrade $\gamma$-aminobutyric acid, a precursor of homocarnosine. Indeed, low levels of homocarnosine synthesis can be observed when degradation of $\gamma$ aminobutyric acid is experimentally inhibited (Bauer et al., 1982). In primary cultures from the rodent olfactory bulb, it has been suggested that carnosine 
synthesis is restricted to the ensheathing cells (Bakardjiev, 1997). Recent studies, carried out on glial cell cultures highly enriched either in astrocytes or in oligodendrocytes, have shown that carnosine synthesis is confined to oligodendrocytes, whereas astrocytes would be capable of carnosine uptake (Hoffmann et al., 1996). An uptake of carnosine, as an energy- and sodiumdependent process, was previously reported by astroglia-rich brain cultures (Schulz et al., 1987).

These results suggest that the dipeptide could exert its function in the extracellular spaces, although such a role is at present unknown. Interestingly, a glutamate receptor-mediated release of carnosine and $\beta$-alanine, dependent on elevated intracellular $\mathrm{Ca}^{2+}$, has been shown to occur in oligodendrocytes (Bakardjiev, 1998). Oligodendrocytes possess several neurotransmitter receptors and respond to glutamate with depolarization and increase of intracellular $\mathrm{Ca}^{2+}$ (Kastritsis and McKarthy, 1993; Berger et al., 1994). Thus, one can not exclude that carnosine and related molecules could play a role in extracellular glia-neuron interactions.

\subsection{Carnosine-LI In The Subependymal Layer}

\subsubsection{The Subependymal Layer (SEL): A Relatively "Young" Region In The Adult Brain}

The SEL is a remnant of the primitive subventricular zone (SVZ), namely the germinal layer wherein neurons and glial cells are formed during development (Boulder Committee, 1970). In the adult the SEL persists within a restricted area of the forebrain corresponding to the anterior part of the lateral ventricles and to the primitive olfactory ventricles. At the ventricular level the SEL lines the lateral wall, in subependymal position. More anteriorly, due to the postnatal occlusion of the olfactory ventricles, it appears as a strip of tissue referred to as the rostral extension, which has lost any relationship with the ventricular cavities (Fig. 6). At this level, only scattered residual ependymal cells can be occasionally seen in the adult (Peretto et al., 1997).

The concept of the SEL as a "young" region of the adult brain, other than referred to its persisting "embryonic" features, is linked to the very recent finding that several striking potentials in structural plasticity (i.e., cell proliferation, cell migration, putative stem cell compartment) occur in this region (Peretto et al., 1999). The persistence of mitotic activity in the SEL of the adult rodent forebrain is known since the 60s (Smart, 1961; Altman, 1969). In the last decade, it has been clearly demonstrated that a great number of newly generated cells actually survive and migrate towards the olfactory bulb, wherein they are thought to differentiate into neurons (Luskin, 1993; Lois and Alvarez-Buylla, 1994). The entire mass of these migrating cells moves tangentially along the SEL, being particularly concentrated into the rostral extension, where it is referred to as the rostral migratory stream (Altman, 1969; Lois and Alvarez-Buylla, 1994). The SEL of the adult rat (Peretto et al., 1997) and mouse (Jankovski and Sotelo, 1996; Lois et al., 1996) contains a meshwork of astrocytic cells and processes organized to form longitudinally oriented channels (glial tubes). Recent light and electron microscopic studies have showed that the newly generated neuronal precursors of the SEL form tangentially oriented chains which are specifically contained within the glial tubes (Garcia-Verdugo et al., 1998; Peretto et al., 1999). Thus, the cellular composition of the SEL involves at least two well separated compartments: the 
glial cells of the tubes and the chains of newly generated, undifferentiated cells (Fig. 6). These compartments can be clearly identified on the basis of their ultrastructural features or by light microscopic immunocytochemical detection of specific markers (reviewed in Peretto et al., 1999). Glial tubes are
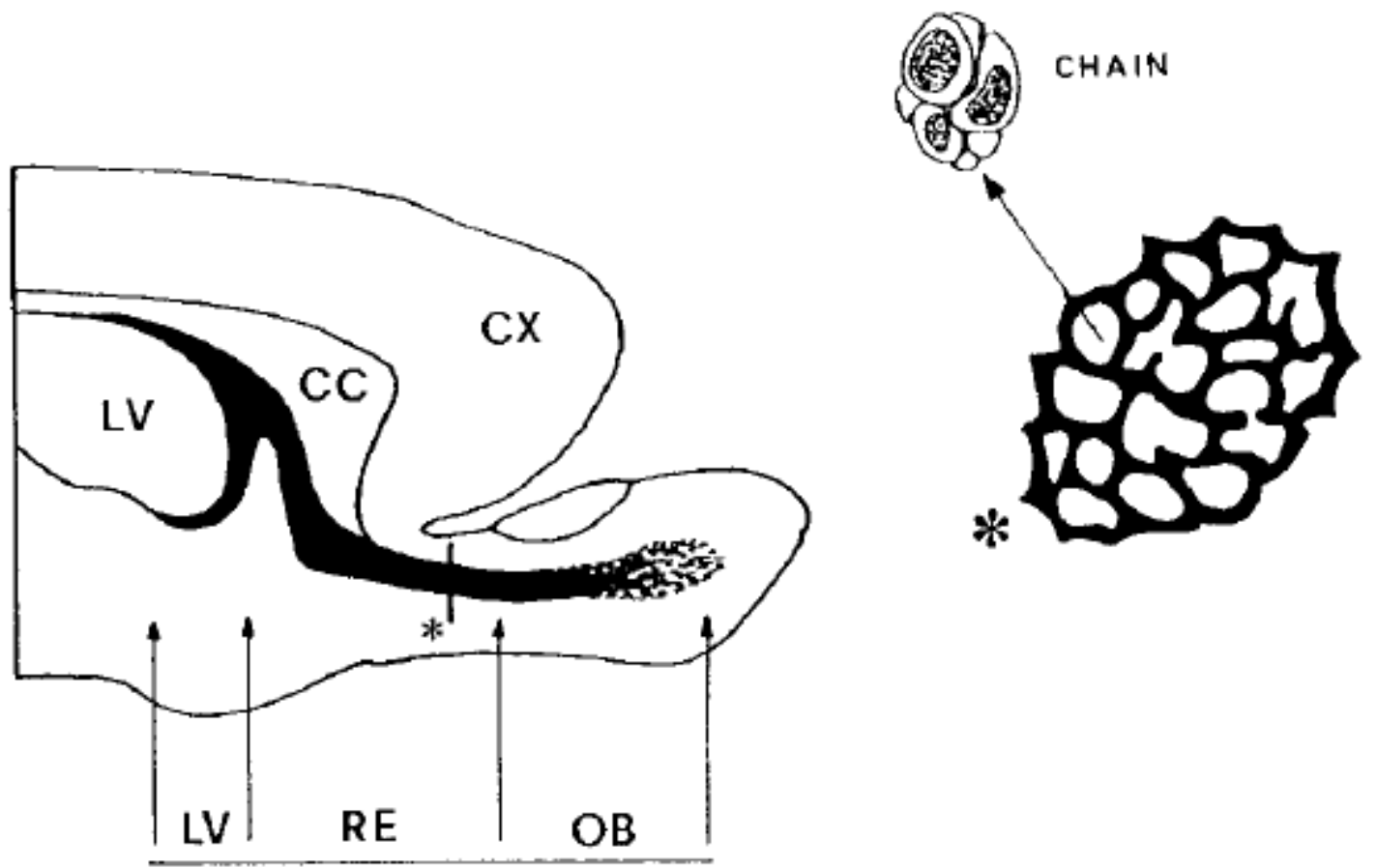

SEL

Fig. 6. Schematic representation of the subependymal layer (SEL) in the brain of adult rodents. In parasagittal view (left), the SEL (black area) can be divided into: a portion lining the anterior part of the lateral ventricle (LV) and the SEL rostral extension (RE). The anterior part of this latter $(\mathrm{OB})$, located along the main axis of the olfactory bulb, appears larger and ill-defined. In the SEL two cell compartments are distinguishable, which can be easily recognized in coronal sections cut at the level of the rostral extension (asterisk and right): astrocytic glial tubes (thick black lines) and chains of migrating neuronal precursors. For more details, see Peretto et al, 1999. CC, corpus callosus; CX, cerebral cortex.

detectable by antibodies raised against two cytoskeletal proteins: the glial fibrillary acidic protein (GFAP, Jankovski and Sotelo, 1996; Lois et al., 1996; Peretto et al., 1997), usually expressed in mature astrocytes (Bignami et al., 1972), and vimentin (Peretto et al., 1997), which is abundant in immature glial cell populations, ependymal cells, Bergmann glia and radial glia (Pixley and De Vellis, 1984). The chains of migrating cells can be specifically identified using antibodies raised against the polysialylated form of the neural cell adhesion molecule (PSA-NCAM, Bonfanti and Theodosis, 1994; Rousselot et al., 1995; Peretto et al., 1997), the neuron-specific, class III $\beta$-tubulin, (Menezes and Luskin, 1994), and the phosphoprotein stathmin (Camoletto et al., 1997). As they reach the olfactory bulb, the behaviour of these cells undergoes striking changes: (i) they leave the SEL and the glial tubes (which become ill defined at this level, see Peretto et al., 1997), spreading in a fan-shaped manner through the granule and periglomerular layers; (ii) they cease to be organized in tangentially oriented chains, now moving as isolated, radially oriented neuroblasts (Luskin, 1993; Bonfanti and Theodosis, 1994; Lois and Alvarez-Buylla, 1994). Thus, cell migration in the SEL is now regarded as a unique type of tangential migration since it occurs in the adult mammalian brain, involves bulks of cells organized to form chains, and use a particular type of glial guidance which is different from the embryonic radial glia. 
The recent demonstration that a population of newly generated cells and an unusual concentration of astrocytic glial cells do coexist in the SEL of adult rodents, along with the fact that olfactory receptor neurons and brain astrocytes were previously considered to be the main cell populations expressing carnosine in the mammalian nervous system, led to a further, detailed analysis about the distribution of carnosine-related dipeptides in the forebrain.
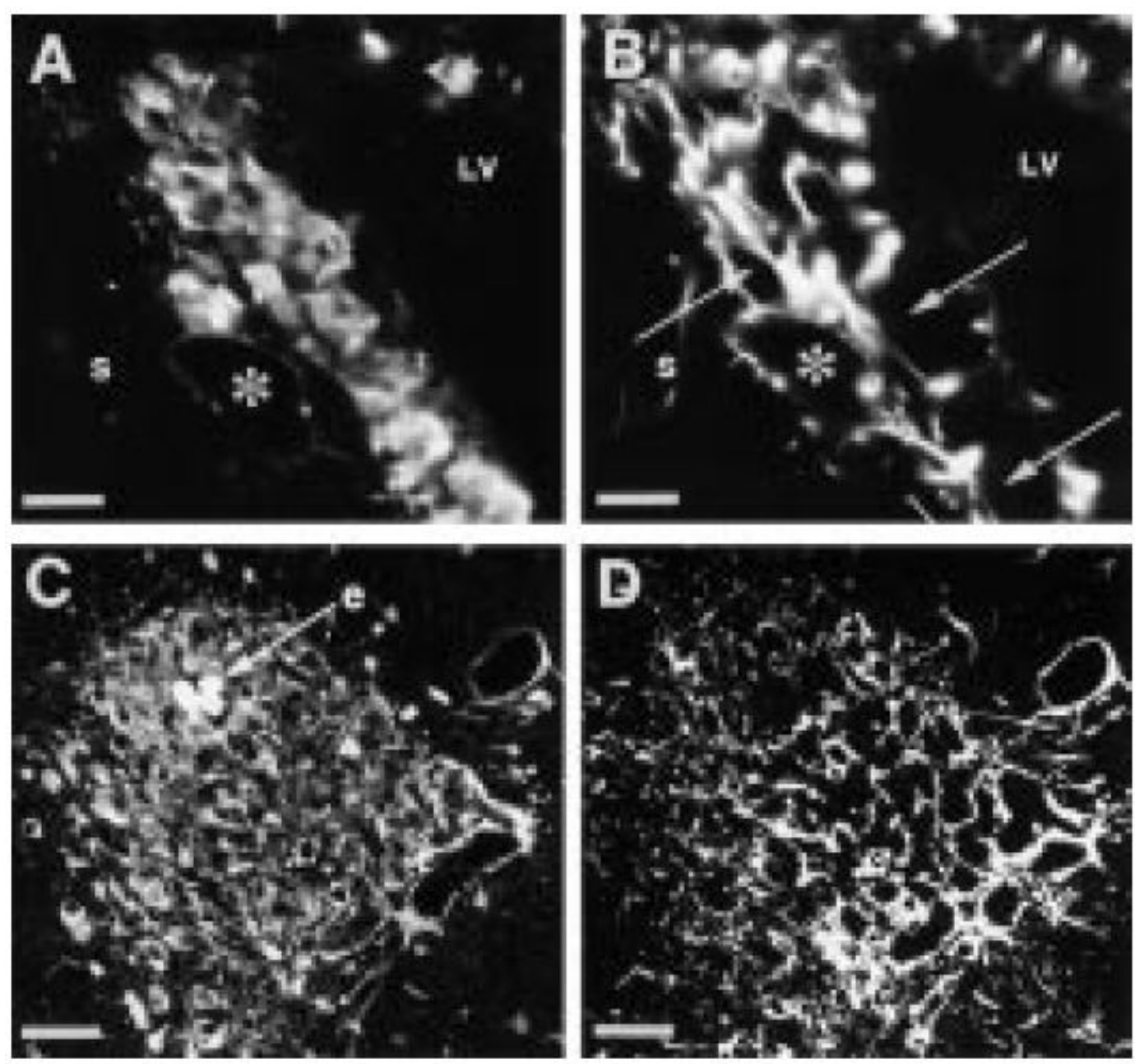

Fig. 7. Distribution of carnosine-LI in the SEL of adult rodents. $A, B$, Double labelling for carnosine (A) and GFAP (B) in the lateral wall of the lateral ventricle (LV) of the adult mouse. The dipeptide is highly expressed in the SEL, adjacent to the striatum (S), including both the astrocytic cells forming the glial tubes and cells which are contained in their lumina (arrows). A blood vessel is indicated by the asterisk. C,D, Coronal section cut at the level of the SEL rostral extension of the adult rat: simultaneous localization of carnosine (C) and GFAP (D), showing the distribution of carnosine-LI in the area occupied by the glial tubes. Two blood vessels are visible on the right. Note a small cluster of three, highly-immunoreactive residual ependymal cells (e). Carnosine-LI is also associated to scattered, stellate glial cells in the tissue surrounding the SEL and to the glial coverage of blood vessels. Calibration bars: $A, B, 7.5 \mu \mathrm{m} ; C, D, 40 \mu \mathrm{m}$.

\subsubsection{Distribution Of Carnosine-LI In The Diferent SEL Compartments And In The Olfactory Bulb Of Adult Rodents}

The distribution of carnosine-LI in the forebrain of adult rodents has been recently investigated in detail by using immunocytochemical techniques (Peretto et al., 1998). The occurrence of a high concentration of carnosine-LI was found in the SEL of rats and mice. In the rat, wherein the two SEL compartments are clearly distinguishable (see Peretto et al., 1997), this study 
was particularly detailed, and was extended to the postnatal period (see section 3.2.3).

Along the SEL, carnosine-LI has been found to be associated with a high number of small tightly-packed cells, showing a cytoplasmic and, to a lesser extent, nuclear reaction (Figs. 7A and $C$, and $8 \mathrm{~A}$ and $\mathrm{C}$ ). Even in the posterior and ventral parts of the ventricular wall, where the SEL is thinner, ill defined and appears in the form of scattered clusters of undifferentiated cells (Smart, 1961; Altman, 1969), the strict overlap between carnosine-LI and the SEL tissue was evident. Both in the ventricular part and in the rostral extension, the pattern of immunoreactivity appeared very dense, thus masking cellular details and preventing the distinction between the compartments formed by the glial tubes and their content (Figs. 7A and $C$, and 8A). Double labellings with carnosine and glia-specific antigens showed a strong carnosine-LI in correspondence of the astrocytic glial meshwork (Fig. 7). However, double labellings with markers which are known to identify the chains of migrating cells (PSA-NCAM, stathmin, class III $\beta$-tubulin; see above for references) confirmed that many carnosine-LI cells also fill the lumina of the glial tubes. Moreover, after in vivo identification of the actively proliferating cells by immunocytochemical detection of systemically-administered 5-bromo-2'deoxyuridine (BrdU), and subsequent double labelling with carnosine, it has been shown that the dipeptide actually is present in new formed cells (Peretto et al., 1998). The high concentration of the double-labelled cells in the horizontal arm of the SEL rostral extension 5 days after BrdU injection, confirms that most of them are migrating cells (see Bonfanti et al., 1997; Peretto et al., 1997).

Interestingly, clusters of tightly-packed, carnosine-LI cells can be frequently observed in close apposition to the wall of blood vessels located within the SEL or in its immediate vicinity (Fig. 8C). These clusters are different from the carnosine-positive (and GFAP-positive) thin glial coverage, which is detectable on blood vessels throughout the brain tissue (see for example Figs. 7C, 8A). Along the SEL rostral extension, the immunoreactivity is also present in residual ependymal cells, recognizable for their larger size and very strong carnosine immunoreactivity (Figs. 7A, 8A). However, it can be excluded that most of the carnosine-LI, non glial cells of the SEL are residual ependymal cells, since these latter are occasionally observed and easily recognizable for their strong vimentin immunoreactivity (an antigen which is not expressed in the chains of migrating cells; Fig. 8B).

The overlap between carnosine-LI and the chains of undifferentiated cells was more evident in the medium/posterior part of the SEL, including the lateral ventricle and most of the rostral extension. By contrast, in the SEL of the olfactory bulb the accumulation of carnosine-LI cells was less evident, being mainly restricted to astrocytes. Due to the fact that the SEL of the olfactory bulb is more enlarged and ill-defined in comparison with the rostral extension (Peretto et al., 1997), at this level it is not easy to clearly identify a limit between the carnosine-LI cells in the SEL and those scattered in the surrounding tissue. Outside the SEL carnosine-LI was restricted to stellate, gliallike cells, and no coexistence of PSA-NCAM or stathmin and carnosine was detectable at this level (if one excludes the olfactory nerve afferent fibers in the glomerular layer, which abundantly contain PSA-NCAM and carnosine; see Bonfanti et al., 1997). In other words, carnosine-LI was not observed in newly generated/migrating cells located outside the SEL and corresponding to the 
radially oriented part of the migratory pathway (Fig. 9).

Thus, one can conclude that carnosine-related dipeptides are detectable in the whole SEL, but not in the entire migration pathway, being restricted to the astrocytic glial tubes and to migrating cells which move within these tubes.

\subsubsection{Distribution Of Carnosine-LI In The Postnatal Rat Forebrain}

\subsubsection{Carnosine-LI is detectable starting from the third postnatal week}

It is well known, from biochemical and immunocytochemical analyses (Margolis et al., 1985; Biffo et al., 1992a), that carnosine and carnosine synthetase activity are detectable in the olfactory system of rodents starting from the embryonic day 16, before the formation of synaptic connections between the olfactory neurons and their targets in the olfactory bulb (Hinds and Hinds, 1976). By contrast, in the brain no aminoacyl-histidine dipeptides are detectable in the perinatal period, apart from the olfactory neuron projections reaching the olfactory bulb (Fig. 10A and B; see also Biffo et al., 1990). In a recent study by Peretto et al. (1998) carnosine-LI was observed at P9 in ependymal but not subependymal cells, and no immunoreactivity was found in the SEL up to P13. Thus, in the rat forebrain, if one excludes the ependymal cells and the axonal projections from the olfactory neuroepithelium, carnosine$\mathrm{LI}$ is first detectable at P13 as a faint reaction in some glial-like cells of the SEL, and at P17 involving a considerable number of glial-like cells scattered in the olfactory bulb and elsewhere in the brain, with a prevalent localization in white matter. Between P21 and P25 virtually all the SEL area was filled by a great number of tightly packed carnosine-positive cells, making it difficult to distinguish between glial and other cell types (Fig. 10C). Starting from P25 and in the subsequent postnatal stages examined, the distribution of carnosine-LI in the SEL was overlapping to that described in the adult.

In animals treated with BrdU during the first three postnatal weeks, newly generated cells showing BrdU-positive nuclei were observed both in the SEL area and in the surrounding tissue, whereas starting from P17-P21 they were progressively concentrated within the SEL. Using double labelling techniques, since from the first appearance of carnosine-LI the presence of the dipeptide was observed in all the BrdU-positive cells in the SEL, but not in the newly generated cells located in the outside tissue. From P25-P30 the BrdU-positive cells were detected exclusively in the SEL, with a distribution similar to that described in the adult. 

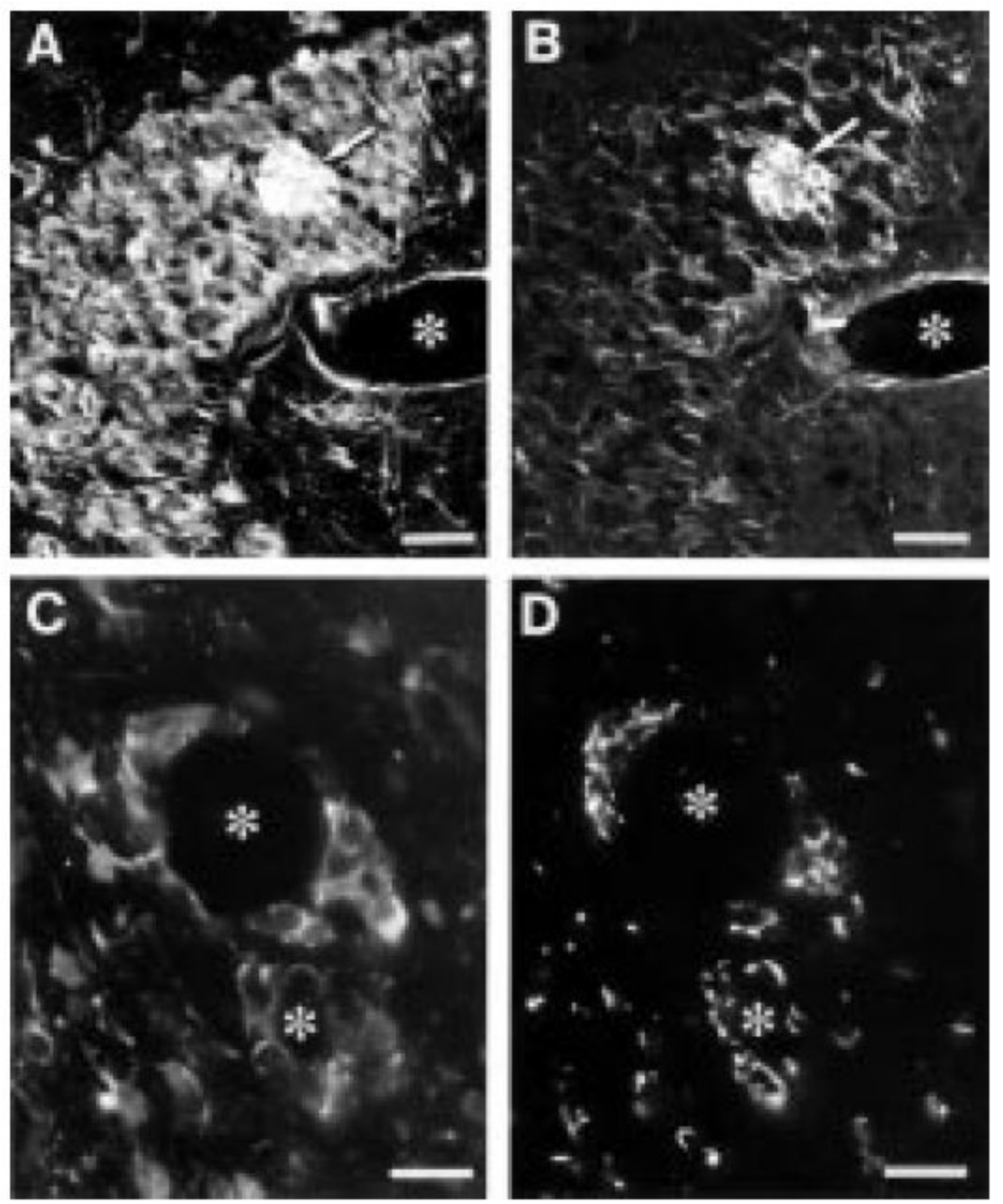

Fig. 8. Immunoreactivity for carnosine and other antigens in the SEL rostral extension of the adult rat (coronal sections). A,B: double labelling for carnosine (A) and vimentin (B), showing a coexistence of the two molecules in a group of residual ependymal cells (arrow), and in the glial wall of the tubes, but not in their content. A coexistence of carnosine and vimentin is also visible in some glial processes contacting the blood vessel (asterisk). C,D: Simultaneous localization of carnosine (C) and PSA-NCAM (D) in clusters of globose cells which are in close contact with two blood vessels (asterisks). Calibration bars: A, B, $30 \mu \mathrm{m} ; C, D, 15 \mu \mathrm{m}$.

Thus, a consistent carnosine-LI is detectable in the SEL starting from the end of the third postnatal week, at the same time when cell proliferation/migration phenomena are disappearing in most of the brain and become restricted to the SEL area. Ongoing studies (De Marchis et al., in preparation) on the distribution of carnosine-LI in the nervous system of developing and young rats confirm that carnosine/homocarnosine progressively appear in CNS glial cells during the first three postnatal weeks, and indicate their earlier occurrence in oligodendrocytes. 
3.2.3.2. The first appearance of carnosine- $\mathrm{LI}$ in the $\mathrm{SEL}$ is visible when striking changes take place in the organization of this area

To get some insights about the structural changes occurring in the SEL during the early postnatal period, the distribution of the markers for chain migration PSA-NCAM and stathmin was examined (Peretto et al., 1998). Strong similarities were observed among the distribution of these two antigens at all the postnatal stages examined. From P2 to P17 a rather uniform widespread staining was detected in different levels of the forebrain. At these stages, the immunoreactivity observed in the tissue surrounding the SEL did not appear less intense than in the SEL itself. By contrast, starting from P21 the immunoreactivity for PSA-NCAM and stathmin appeared evidently increased within the SEL, whereas a dramatic decrease in the immunostaining occurred in the surrounding tissue. Also within the SEL, the distribution of these markers underwent striking changes: up to P17, they were both observed in a mass of cells uniformly arranged in the SEL area, whereas starting from P21 they were associated to cell chains.

By using antibodies raised against vimentin, an intermediate filament protein which is abundant in immature glia, the organization of glial cells in the SEL was also examined. In early postnatal stages the typical astrocytic arrangement known to form the glial tubes in the adult was not observed, but a rather homogeneous network of randomly-oriented glial processes was present (Peretto et al., 1999). Although some of these processes were longitudinally oriented, during the first two postnatal weeks they did not form thick septa capable of compartmentalizing the SEL. By contrast, starting from P17 and more evidently at P21-P25, a high density of glial cells forming well delineated tubes and separating chains of undifferentiated cells was clearly visible throughout the SEL.

In conclusion, the first appearance of carnosine-LI in the SEL (around P21) occurs in coincidence with striking changes occurring in this area, involving the organization of migrating cells in chains and that of astrocytes into glial tubes. 

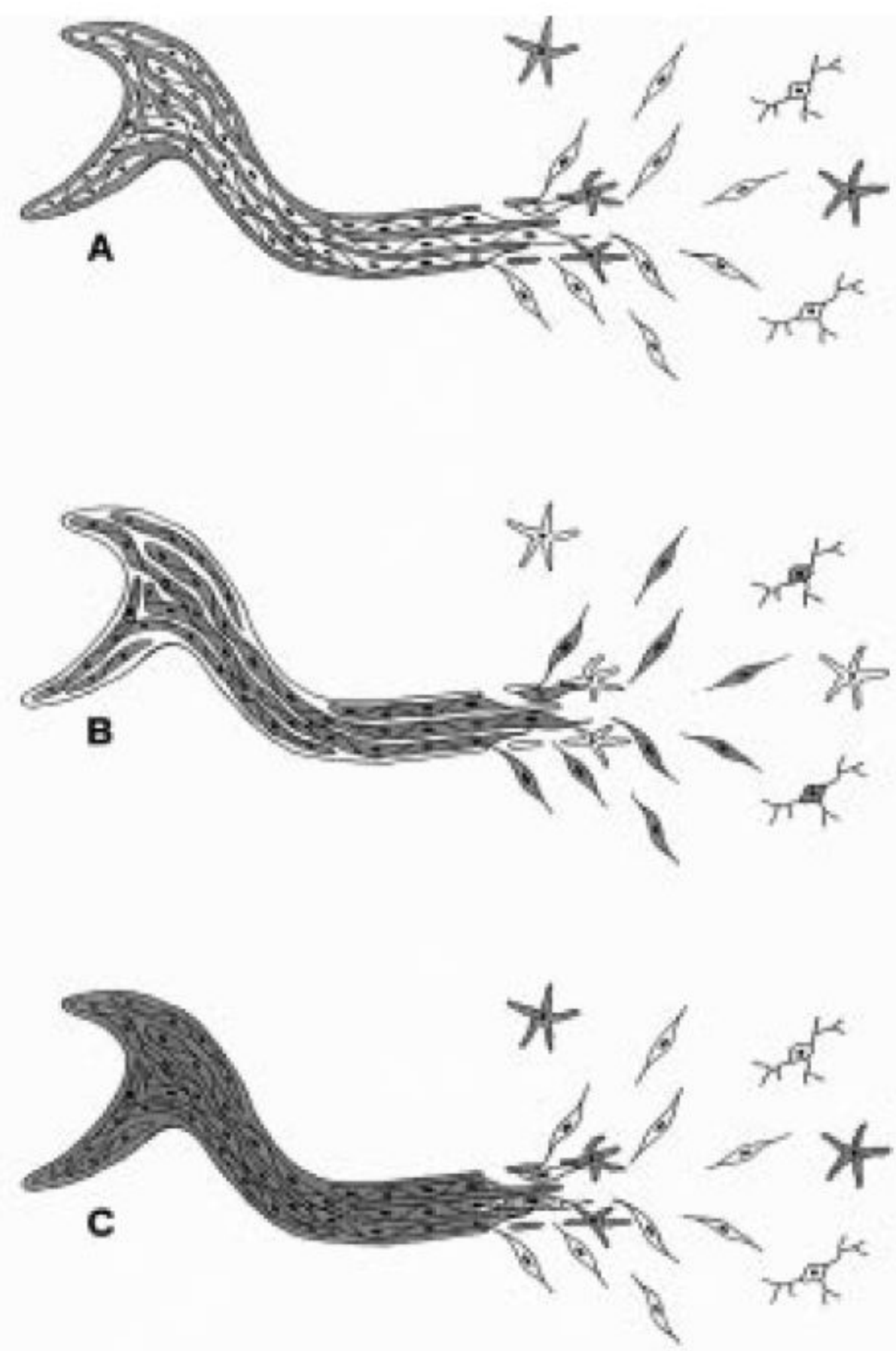

$\angle-2$ - chain of migating cels
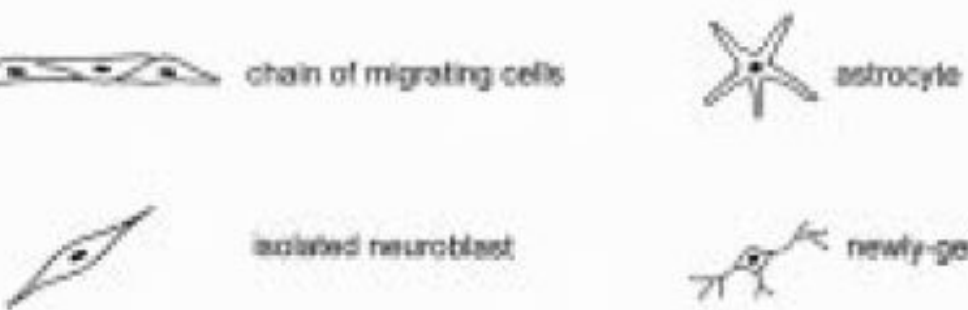

andamed rauroblingt

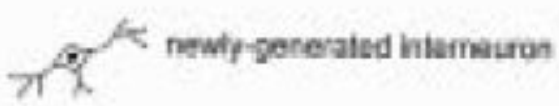

Fig. 9. Schematic drawing showing the pattern of distribution of different molecules (in gray) in the SEL of the adult rat and in the whole migratory pathway to the olfactory bulb. Antigens usually expressed by mature (GFAP) or immature (vimentin) astrocytes, are restricted to the glial tubes (A), which depict the entire SEL area, although they became ill-defined in the most anterior part. Other molecules, such as PSA-NCAM and stathmin, are considered markers of the entire migratory pathway (B), revealing newly-generated cells which form tangentially oriented 
chains in the SEL and those which spread radially in the olfactory bulb as isolated neuroblasts. Carnosine-LI (C) is visible in the SEL area, associated both with astrocytes of the glial tubes and chains of migrating cells. Note that carnosine-LI is hardly detectable in cells migrating within the SEL of the olfactory bulb, and it is absent in the isolated neuroblasts moving through the olfactory bulb.
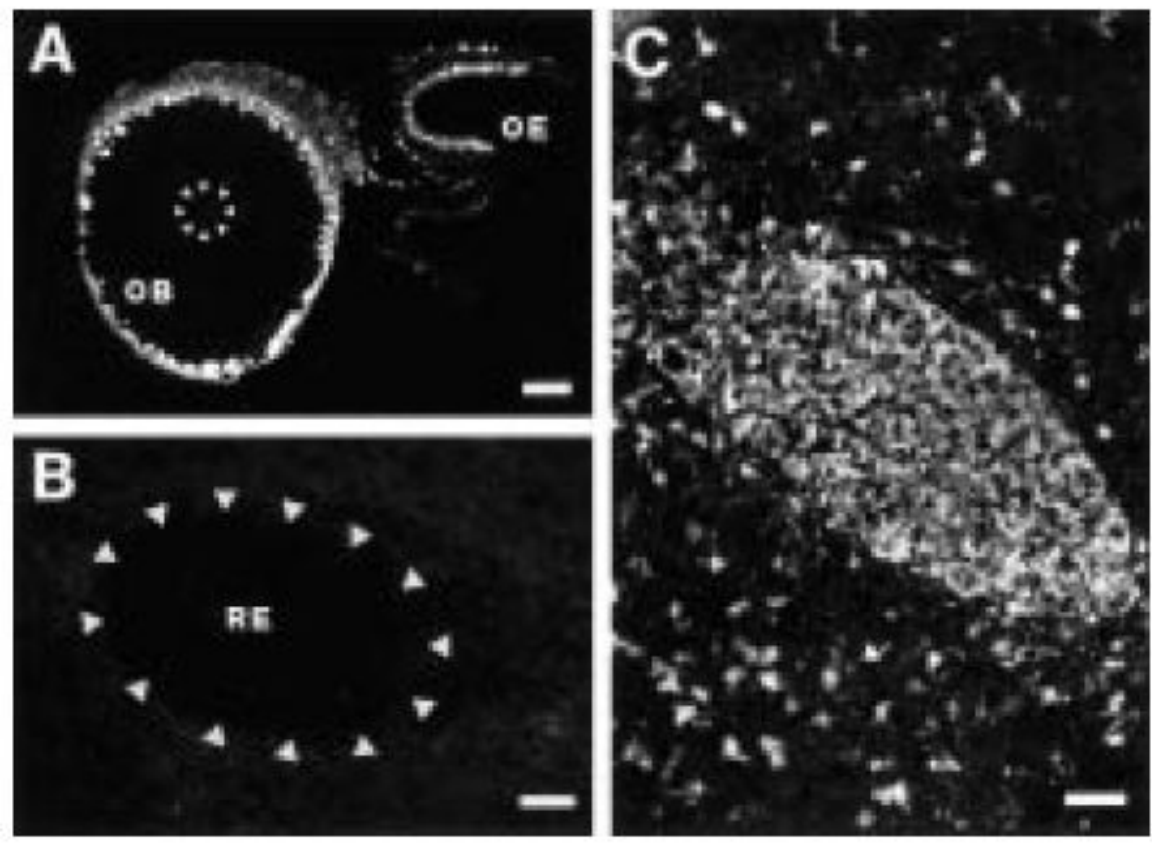

Fig. 10. Immunoreactivity for carnosine in the olfactory system and forebrain of the postnatal rat. Animals killed at P9 $(A, B)$ and at P21 (C). Striking carnosine-LI is visible at P9 in the olfactory receptor neurons of the olfactory epithelium (OE) and in their axonal projections to the glomerular layer of the olfactory bulb (OB), but not in the SEL (the limit between the SEL area and the surrounding tissue is indicated by arrowheads). Also at more posterior levels (in $\mathrm{B}$ ), no carnosine-LI is detectable at P9 in the SEL rostral extension (RE). At the same level, at P21 (C) a strong carnosine-LI is present in the SEL, as well as in glial cells of the surrounding tissue. Calibration bars: A, $200 \mu \mathrm{m} ; \mathrm{B}, 60 \mu \mathrm{m}$; C, $30 \mu \mathrm{m}$.

\subsection{Conclusions}

Studies carried out in many regions of the mammalian brain have concluded that the localization of carnosine-related dipeptides in glia involves two distinct cell types: astrocytes and oligodendrocytes. In vitro experiments indicate the selective capacity of different glial cell populations to synthesize (oligodendrocytes) or take-up (astrocytes) the dipeptides. These results raise the question as to whether the two glial cell populations display the same behaviour in vivo, a problem which can not be easily answered by immunocytochemistry (see sections 1.1 and 3.1.1).

In vivo, carnosine-LI is present in a wide range of cells belonging to the astrocytic lineage, such as cerebellar Bergmann glia, radial glia-like cells of the supraoptic nucleus, and cells which are considered of the glial lineage, such as ependymal cells and tanycytes (Flament-Durand and Brion, 1985; Bruni, 1998). Interestingly, it is abundant in the subfornical organ, a circumventricular structure which contains tanycytes and glial cells, and is endowed with fenestrated capillaries that permit the passage of blood-borne molecules (Dellmann, 1998).

Moreover, strong carnosine-LI is detectable in the SEL, an area of persisting neurogenesis in the adult forebrain. The SEL is composed of small tightlypacked cells apparently forming an homogeneous tissue, but which actually 
involves two distinct cellular compartments: (i) the newly generated, migrating cells, which are organized to form chains, and (ii) the astrocytes of the glial tubes, in which the chains are contained. Unlike most of the antigens previously localized in this system, which usually are restricted to one of the two cellular compartments, carnosine-LI is associated with both of them.

The presence of carnosine in astrocytes of the glial tubes was expected since the dipeptide is abundant in most of the astrocytic cells of the adult brain. On the other hand, the finding of carnosine-LI in newly generated cells of the SEL, which are generally regarded as neuronal precursors (Luskin, 1993; Lois and Alvarez-Buylla, 1994), raises more interest. Carnosine-LI is detectable through the entire length of the SEL, namely the area in which cell proliferation and migration coexist. However, the migration pathway to the olfactory bulb is divided into two parts characterized by important differences concerning cell migration (see above), and carnosine-LI was detected only in the first part of this pathway. This suggests that the dipeptide is transiently expressed by cells which move tangentially within the SEL, and form chains, whereas it is absent in the same cells when they migrate radially outside the SEL, as isolated neuroblasts. Thus, it is reasonable to speculate that the transient expression of the dipeptide in migrating cells could be related to their organization in chains and/or to their relationships with glial structures. In our opinion, the hypothesis of a link between carnosine expression and chain migration appears more likely since it has been recently shown in vitro that cells of the SEL also can undergo this type of migration in a glia-independent manner (Wichterle et al., 1997). Moreover, studies carried out in postnatal rats demonstrated that a carnosineLI comparable in density and pattern of distribution to that described in the adult is detectable in the SEL starting from P21. This stage coincides with the first visualization of well organized chains of migrating cells enwrapped by glial tubes. Since long distance, tangential cell migration has been demonstrated to occur in the forebrain of neonatal and postnatal rats (Luskin, 1993), carnosine could not be linked to cell migration itself. Its appearance seems rather related to important changes occurring in this area around the third postnatal week, involving its cellular organization, in terms of relationships among the different SEL compartments (Peretto et al., 1999).

\section{HYPOTHETICAL FUNCTIONS OF CARNOSINE-RELATED DIPEPTIDES IN THE NERVOUS SYSTEM}

Although many theories have been proposed about the biological function(s) of these molecules in the nervous system or elsewhere, none of them have been compellingly substantiated. Among the hypotheses proposed, two have received more attention and have been extensively investigated: one concerns the role of the various aminoacyl-histidine dipeptides in several types of tissues, functioning as in vivo antioxidants (Hipkiss, 1998), the other is restricted to a putative effect of carnosine as a neurotransmitter/modulator in certain neuronal systems (Margolis, 1980).

\subsection{Antioxidant Effect}

As quoted in the Introduction, carnosine-related dipeptides are usually abundant in excitable tissues, such as muscle and brain. These compounds can exert a nonspecific buffering function during muscle performance; however, this property seems to be restricted to muscle tissue and plays only an 
accessory role in the overall potent buffering effect of cytosolic proteins/components (Boldyrev et al., 1988). On the other hand, it is well known that some physiological processes such as muscle performance and electrical conduction along nerve fibers involve free radical lipid peroxidation in biological membranes, and that skeletal muscle and brain are two of the tissues which have the most active oxidative metabolism (Vladimirov and Archakov, 1972; Evans, 1993). By contrast, these tissues do not possess very high concentrations of antioxidants vitamins E and C (Hornig, 1975; Kornbrust and Mavis, 1979). In particular, neurons contain very low levels of reduced glutathione, an antioxidant responsible for removal of cytosolic peroxides (Slivka et al., 1987), and their membranes contain a high proportion of freeradical-susceptible polyunsaturated fatty acids (see Evans, 1993). Interestingly enough, several studies demonstrated a significative antioxidant activity for carnosine-related dipeptides, both in muscle and brain tissue (see for example Boldyrev et al., 1987, 1988, 1997; Kohen et al., 1988; Boldyrev, 1993). The activity showed by these dipeptides is due to the imidazole moiety of the molecule, and consists of several anti-oxidant properties, i.e. stabilization of membranes (Boldyrev et al., 1988), scavenging of free radical intermediates (Kohen et al., 1988; Salim-Hanna et al., 1991; Pavlov et al., 1993), chelation of divalent transition metals such as iron, copper and zinc (Brown, 1981; Kohen et al., 1988; Klebanov et al., 1998), elimination of lipid peroxidation products in a nonenzymatic way (Boldyrev et al., 1987; Dupin et al., 1987). These properties are strictly related to each other; for example, important compounds in free radical biochemistry, such as hydrogen peroxide, in the presence of transition metal ions produce the more reactive and damaging hydroxyl radical (Cheeseman and Slater, 1993). Recent studies, carried out on cultured fibroblasts, described an antisenescent effect of carnosine (McFarland and Holliday, 1994). Since oxidative DNA damage is considered one of the main causes of cellular senescence, such an effect is probably linked to the antioxidative properties of the dipeptide. Indeed, treatments with carnosine significantly reduce the formation of 8-hydroxy deoxyguanosine (one of the major products of oxidative DNA damage, Fraga et al., 1990) in fibroblast cell cultures (Sri-Kantha et al., 1996), and exert protective effects against malondialdehyde (a deleterious end-product of lipid peroxidation) in cultured brain endothelial cells (Hipkiss et al., 1997).

\subsection{Inhibition Of Protein Glycosylation}

Carnosine has been shown to act as a competitive inhibitor of non-enzymic glycosylation of proteins (Hipkiss et al., 1995). This consists of a series of posttranslational modifications in which protein amino groups and side chains react non-enzymatically with monosaccharides (forming the so called 'Amadori products'; Munch et al., 1997). The potential of carnosine to react with sugars is linked to its aminoacid sequence, which is similar to Lys-His, namely the preferred glycation sites in proteins (Shilton and Walton, 1991; Hipkiss et al., 1995). In the process of protein glycosylation, subsequent oxidations and dehydrations lead to the formation of a wide range of products referred to as advanced glycation endproducts (AGEs). The accumulation of AGEs in the brain, as a cause of ageing/degeneration, has been proposed to play a direct role in the etiology and pathogenesis of Alzheimer's disease (Smith et al., 1995; Munch et al., 1997). Moreover, the reactions leading to the AGEs formation are accelerated by transition metals (which oxidize the protein-bound Amadori 
products) and involve the formation of oxigen free radicals.

Thus, it appears evident that carnosine possesses a wide range of properties which enable it to act in different, but related, ways (as antioxidant, metal chelator, free radical scavenger, inhibitor of protein glycosylation), to prevent several types of damage responsible for cell senescence.

\subsection{Putative Neurotransmitter}

The detection of high levels of carnosine in the olfactory system of several mammalian species (Margolis, 1974; Neidle and Kandera, 1974; Wideman et al., 1978; Burd et al., 1982) including humans (Kish et al., 1979), and its specific localization in the olfactory receptor neurons (Sakai et al., 1987, 1990; Biffo et al., 1990), led to the hypothesis that the dipeptide could exert a putative role in neurotransmission within this sensory system (Margolis, 1974, 1978,1980 ). The olfactory receptor neurons (primary olfactory neurons) are typical bipolar neurons located among non-neuronal supporting cells in the olfactory neuroepithelium lining the nasal cavity (Fig. 1). These receptor cells send their axon to the glomerular layer of the olfactory bulb, where they make synapses with the dendrites of mitral, tufted and periglomerular cells. Immunocytochemical studies carried out at both the light and electron microscopical level, clearly showed that carnosine is contained within these axons (Sakai et al., 1987; Biffo et al., 1990) and in their synaptic terminals (Sakai et al., 1988; Sassoè Pognetto et al., 1992, 1993). At present, the aminoacid glutamate is the main excitatory neurotransmitter candidate in several sensory systems (Nicholls and Attwell, 1990), including the primary olfactory pathway (Berkowicz et al., 1994). By using post-embedding immunogold techniques, the coexistence of carnosine and glutamate has been demonstrated in the synaptic terminals of the mouse olfactory neurons (Sassoè-Pognetto et al., 1993), as well as in hair cells of the inner ear (Panzanelli et al., 1994) and photoreceptors of frogs (Panzanelli et al., 1997). These data, along with the existence of carnosine synthetase and carnosinase activities in the olfactory bulb and mucosa (higher than in other brain regions or tissues, Margolis, 1978; Harding and O'Fallon, 1979) and of binding sites for carnosine in the olfactory bulb (Hirsch et al., 1978; Hirsch and Margolis, 1979), support the hypothesis for an unknown role of the dipeptide carnosine in neuromodulation in glutamatergic sensory neurons. Nevertheless, biochemical studies indicated that carnosine is localized in the cytosol of the olfactory bulb and epithelium, not associated with synaptic vesicles (Harding and O'Fallon, 1979); indeed, morphological studies carried out using high resolution techniques were not able to clearly show a high concentration of the dipeptide in synaptic vesicles (Sassoè-Pognetto et al., 1993). A calcium-dependent depolarization stimulated release of carnosine has been shown in olfactory bulb synaptosomes (Rochel and Margolis, 1982) and inward current responses have been induced in olfactory bulb cultured slices after application of carnosine (Kanaki et al., 1997); however, it is known that carnosine leaks out of tissue during preparation of synaptosomes or tissue slices and can also be released as a slow spontaneous process which is independent of depolarization (Margolis, 1974; Rochel and Margolis, 1982). Definitive physiological evidence for a role of this dipeptide in neurotransmission is at present unavailable. Indeed, in vivo studies have provided conflicting results. Direct injection of the dipeptide into the olfactory bulb glomerular layer of rabbits revealed an increase in frequency of evoked potentials within the first minute after injection 
(Gonzalez-Estrada and Freeman, 1980), but carnosine applied by microiontophoresis in the rat olfactory bulb was mainly without effect on mitral cells (MacLeod and Straughan, 1979). Similarly, Nicoll et al. (1980) found no effect using in vitro preparations of the turtle and frog olfactory bulb. Finally, a glutamate receptormediated release of carnosine and b-alanine, dependent on elevated intracellular $\mathrm{Ca}^{2+}$, has been recently shown to occur in oligodendrocytes (Bakardjiev, 1998), its functional implications being at present unknown.

\subsection{Structural Plasticity}

The presence of carnosine in the olfactory receptor neurons has been generically put in relation with their property to undergo striking plasticity during adulthood. For a long time these receptors were considered as a unique neuronal population capable of intense cell renewal, including a continuous growth of their axonal processes directed to the olfactory bulb (for review see Graziadei and Monti Graziadei, 1978; Brunjes and Frazier, 1986). This feature is linked to the existence of precursor cells in the basal layer of the olfactory neuroepithelium, which assure a continuous neurogenesis throughout life (Caggiano et al., 1994; Calof et al., 1998). However, among the different cell types existing in the olfactory mucosa (basal cells, supporting cells and receptor neurons at different maturation stages; Brunjes and Frazier, 1986; Calof et al., 1998; Fig. 1), the expression of carnosine is restricted to the mature olfactory receptor neurons, as confirmed by double labelling with specific immunocytochemical markers (Margolis, 1972).

\section{CONCLUDING REMARKS}

One century after the first description of carnosine, its role in the nervous system remains unresolved. Several hypothesis have been proposed to explain the function of carnosine and carnosine-related dipeptides in different tissues, as well as in different areas of the nervous system. In the latter, a rather heterogenous distribution involving very different cell populations makes it difficult to build an unified theory. In the past, the high expression of carnosine in the mammalian olfactory receptor neurons suggested a role for this dipeptide as a neurotransmitter/modulator in olfaction (Margolis, 1974, 1978, 1980). However, evidences supporting such an issue are at present inadequate, and do not explain the localization of the dipeptides in other cell populations. Alternatively, carnosine has been linked to the capability of the olfactory receptor neurons to undergo cell renewal throughout life, although no biological functions supporting this assumption have been found.

Recently, consistent carnosine-LI has been described within the SEL of rodents (Peretto et al., 1998), another area of the forebrain wherein neurogenesis continues during adulthood. The SEL and the olfactory neuroepithelium are two regions of the nervous system which share important similarities. They are both part of the olfactory system and are characterized by striking structural plasticity, including neurogenesis, although a long term survival and incorporation of newly generated cells in the olfactory bulb neural circuits have not yet been demonstrated (Garcia-Verdugo et al., 1998; Peretto et al., 1999). Furthermore, both these sites are thought to contain a population of stem cells, although those isolated from the SEL appear to be multipotent (Weiss et al., 1996) whereas the putative stem cells of the olfactory neuroepithelium would 
be restricted to the neuronal lineage (Caggiano et al., 1994; Calof et al., 1998). On the other hand, remarkable differences also exist between these two populations of new formed cells. First, cells generated in the SEL, unlike the olfactory receptors, undergo a long distance migration prior to their differentiation. Second, in the olfactory epithelium carnosine-LI is present in mature olfactory receptors (Sakai et al., 1987), whereas in the SEL it is only transiently detectable in undifferentiated cells of the tangential tract, being absent in migrating and differentiating neuroblasts of the olfactory bulb (Peretto et al., 1998). These observations suggest that carnosine-related dipeptides in the SEL, rather than being involved in the processes of cell renewal, could be associated with the particular type of tangential (chain) migration occurring therein. This idea is supported by the finding of the first appearance of carnosine in this area in coincidence with the first morphological evidence for chain migration (Peretto et al., 1998), and delayed in respect to its earlier expression in olfactory receptor neurons. However, as discussed in section 3.3, it is unlikely that carnosine can be linked to cell migration itself. Therefore, the recent finding of carnosine-LI in the SEL does not help in understanding the role of these molecules in the brain, rather it suggests that they are not related to cell renewal. On the other hand, it is worth noting that most cells of the adult brain containing carnosine-related dipeptides share some features. Interestingly, these cell populations continue to express vimentin during adulthood (Shaw et al., 1981; Pixley and De Vellis, 1984; Bonfanti et al., 1993; Peretto et al., 1997). Vimentin is a cytoskeletal, intermediate filament protein very abundant during development, which can be found in immature glial cells, including radial glia (Bignami et al., 1982; Dahl et al., 1981), and in highly undifferentiated neuronal precursors (Cochard and Paulin, 1984). In adult animals, although mainly replaced by other intermediate filament proteins such as GFAP in glial cells and neurofilament triplet protein in neurons (see Steinert and Roop, 1988; Gorham et al., 1991), vimentin persists in many cell populations which are enriched in carnosine-related dipeptides, namely cerebellar Bergmann glia, ependymal cells, tanycytes, a sub-population of astrocytes in large myelinated bundles (Shaw et al., 1981; Pixley and De Vellis, 1984), radial glia-like cells in the supraoptic nucleus (Bonfanti et al., 1993), astrocytes of the glial tubes (Peretto et al., 1997), and olfactory receptor neurons (Schwob et al., 1986; Gorham et al., 1991). This transition from a precursor type of intermediate filament proteins (vimentin), to more specialized ones, has also been described to occur in skeletal muscle cells (Granger and Lazarides, 1979). The relationship between vimentin and carnosine in cells of the neuronal lineage is intriguing: during development, the expression of vimentin in these cells is restricted to undifferentiated precursors whereas in the adult olfactory neuroepithelium, which contains many undifferentiated neuronal precursors in the basal layer, vimentin is detectable exclusively in the mature olfactory neurons (Schwob et al., 1986; Gorham et al., 1991), namely the cells containing carnosine.

In previous studies, it has been suggested that vimentin expression could be related to the connections with increased extracellular fluid compartments or direct contact with cerebrospinal fluid, primarily due to its localization in ependymal cells and tanycytes (Pixley and De Vellis, 1984). Tanycytes are thought to be involved in protective mechanisms in brain regions which lack a blood-brain barrier (also referred to as circumventricular structures), being exposed to blood-borne substances which have to be continuously removed from the extracellular space (see Wagner and Pilgrim, 1974; Bruni, 1998). 
Among these regions is the subfornical organ, which contains ependymal cells and tanycytes and can act as a chemoreceptive area implicated in the transcellular transport required for water balance (Dellmann, 1998). Besides ependymal cells, glial cells are critically involved in the control of brain volume homeostasis, mediating the flow of water between the cerebrospinal fluid, the intravascular space and the intercellular space, a view recently supported by the identification of specific aquaporins (see for example Nielsen et al., 1997). Also astrocytes in large myelinated tracts, although not in contact with blood vessels, could have some connections with large extracellular spaces, which in white matter are wider than in gray matter (Lee and Bakay, 1966; Klatzo, 1967). More in general, carnosine-LI is abundant in the glial coverage of blood vessels, and a protective effect exerted by this dipeptide on brain endothelial cells has been described (Hipkiss et al., 1997; Preston et al., 1998).

As to the remaining glial cell types, cerebellar Bergmann glia and radial glialike cells in the supraoptic nucleus represent a remnant of the embryonicradial glia (references in Shaw et al., 1981; Pixley and De Vellis, 1984; Bonfanti et al., 1993). Astrocytes of the glial tubes also display some features of radial glia, since they contain vimentin and glycogen granules (Jankovski and Sotelo, 1996; Peretto et al., 1997). Within this context it is worth noting that the SEL, as a remnant of the primitive subventricular zone, retains several embryonic features, among which there is the tendency of the cells to shrink during fixation, leaving enlarged extracellular spaces (Jankovski and Sotelo, 1996; Lois et al., 1996; Peretto et al., 1997). It is accepted that extracellular spaces are wider in the embryonic versus the mature nervous tissue; for example, during the postnatal maturation of the rat cerebral cortex, the extracellular space was found to diminish dramatically during the first three postnatal weeks of age (Bondareff and Pysh, 1968; Caley and Maxwell, 1970). Moreover, the existence of chain migration in the SEL, involving large amounts of neuroblasts which advance at a speed three to six times faster in comparison to that observed during CNS development (see Wichterle et al., 1997), likely implies rapid and striking variations in the extracellular spaces. Similar features, consisting of an "embryonic" environment which persists into a mature tissue, with relevant phenomena of structural plasticity occurring between neurons and glia, have also been described in the hypothalamic supraoptic nucleus (Theodosis and Poulain, 1993), another brain structure involved in osmosensation and regulation of body water balance.

In conclusion, elements containing carnosine-related dipeptides and vimentin, although heterogeneous as to their nature and localization, have at least one portion of the cell contacting wide extracellular space or cerebrospinal fluid, and/or situated in a portion of the nervous tissue which retains embryonic features. The presence of carnosine in the olfactory receptor neurons can be considered within the same context, since the olfactory neuroepithelium is directly exposed to the external environment and is continuously renewed (Biffo et al., 1990). In our opinion, the hypothetical role(s) of carnosine-related dipeptides could be linked to some common feature(s) concerning the metabolism of these cell populations, although no direct evidence in this direction is at present available. Nevertheless, there is strong evidence that carnosine and structurally related dipeptides possess a wide range of properties, such as antioxidant, metal chelator, free radical scavenger, inhibitor of protein glycosilation (Boldyrev et al., 1987, 1988, 1997; Kohen et al., 1988; Boldyrev, 1993; Hipkiss et al., 1995; Preston et al., 1998; for review, see Hipkiss, 1998), which enable them to prevent several types of damage 
responsible for cell senescence (McFarland and Holliday, 1994; Sri-Kantha et al., 1996). Thus, carnosine-related dipeptides could exert a protective role in cell populations of the nervous system which, due to their location and/or function and metabolism, can come in contact with potentially harmful substances. In perspective, the hypotheses discussed in the present review need to be assessed by searching for a link between such protective effects of carnosine and the metabolism of specific cell populations of the mammalian brain.

Acknowledgements - The authors thank Frank L. Margolis for reading the manuscript and for kindly providing the anti-carnosine serum. We also thank Franco Scaranari for his excellent photographic expertise. This work was supported by grants of the Ministero dell'Università e della Ricerca Scientifica e Tecnologica (MURST) and the Consiglio Nazionale delle Ricerche (CNR).

\section{REFERENCES}

Abraham, D., Pisano, J.J., Udenfriend, S., 1962. The distribution of homocarnosine in mammals. Arch. Biochem. Biophys. 99, 210-213.

Abraham, D., Pisano, J.J., Udenfriend, S., 1964. Uptake of carnosine and homocarnosine by rat brain slices. Arch. Biochem. Biophys. 104, 160-165.

Altman, J., 1969. Autoradiographic and histological studies of postnatal neurogenesis. Cell proliferation and migration in the anterior forebrain, with special reference to persisting neurogenesis in the olfactory bulb. J. Comp. Neurol. 137, 433-458.

Artero, C., Marti, E., Biffo, S., Mulatero, B., Andreone, C., Margolis, F.L., Fasolo, A., 1991a. Carnosine in the brain and olfactory system of amphibia and reptilia: a comparative study using immunocytochemical and biochemical methods. Neurosci. Lett. 130, 182-186.

Artero, C., Mulatero, B., Biffo, S., Andreone, C., Gozzo, S., Margolis, F.L., Fasolo, A., 1991b. Distribution of carnosine-like immunoreactivity in the brain of the crested newt. Brain Behav. Evol. 37, 168-178.

Bakardjiev, A., 1997. Biosynthesis of carnosine in primary cultures of rat olfactory bulb. Neurosci. Lett. 227, 115-118.

Bakardjiev, A., 1998. Carnosine and b-alanine release is stimulated by glutamatergic receptors in cultured rat oligodendrocytes. Glia 24, 346-351.

Bakardjiev, A., Bauer, K., 1994. Transport of b-alanine and biosynthesis of carnosine by skeletal muscle cells in primary culture. Eur. J. Biochem. 225, 617-623.

Bascò , E., Woodhams, P.L., Hajòs, F., Balàzs, R., 1981. Immunocytochemical demonstration of glial fibrillary acidic protein in mouse tanycytes. Anat. Embryol. 162, 217-222.

Bate-Smith, E.C., 1938. The buffering of muscle in rigor; protein, phosphate and carnosine. J. Physiol. 92, 336-343.

Bauer, K., Schulz, M., 1994. Biosynthesis of carnosine and related peptides by skeletal muscle cells in primary culture. Eur. J. Biochem. 219, 43-47.

Bauer, K., Salnikow, J., DeVitry, F., Tixier-Vidal, A., Kleinkauf, H., 1979.

Characterization and biosynthesis of $\omega$-aminoacyl amino acids from rat brain and the C-6 glioma cell line. J. Biol. Chem. 254, 6402-6407.

Bauer, K., Hallermayer, K., Salnikow, J., Kleinkauf, H., Hamprecht, B., 1982. Biosynthesis of carnosine and related peptides by glial cells in primary culture. J. Biol. Chem. 257, 3593- 3597. 
Berger, T., MuĖ Iler, T., Kettenmann, H., 1994. Developmental regulation of ion channels and receptors on glial cells. Persp. Develop. Neurobiol. 2, 347-356.

Berkowicz, D.A., Trombley, P.Q., Shepherd, G.M., 1994. Evidence for glutamate as the olfactory receptor cell neurotransmitter. J. Neurophysiol. 71, 25572561.

Biffo, S., Grillo, M., Margolis, F.L., 1990. Cellular localization of carnosine-like and anserine-like immunoreactivities in rodent and avian central nervous system. Neuroscience 35, 637-651.

Biffo, S., Marti, E., Fasolo, A., 1992a. Carnosine, nerve growth factor receptor and tyrosine hydroxylase expression during the ontogeny of the rat olfactory system. J. Chem. Neuroanat. 5, 51-62.

Biffo, S., Sassoè-Pognetto, M., Verdun di Cantogno, L., Perroteau, I., Fasolo, A., 1992b. Bulbectomy enhances neurogenesis and cell turnover of primary olfactory neurons but does not abolish carnosine expression. Eur. J. Neurosci. 4, 1398 - 1406.

Bignami, A., Eng, L.F., Dahl, D., Uyeda, C.T., 1972. Localization of the glial fibrillary acidic protein in astrocytes by immunofluorescence. Brain Res. 43, 429-435.

Bignami, A., Raju, T., Dahl, D., 1982. Localization of vimentin, the non-specific intermediate filament protein, in embryonic glia and in early differentiating neurons. Dev. Biol. 91, 286-295.

Boldyrev, A.A., 1993. Does carnosine possess direct antioxidant activity? Int. J. Biochem. 25, 1101-1107.

Boldyrev, A.A., Dupin, A.M., Bunin, A.Y., Babizhaev, M.A., Severin, S.E., 1987. The antioxidative properties of carnosine, a natural histidine containing dipeptide. Biochem. Int. 15, 1105-1113.

Boldyrev, A.A., Dupin, A.M., Pindel, E.V., Severin, S.E., 1988. Antioxidative properties of histidine-containing dipeptides from skeletal muscles of vertebrates. Comp. Biochem. Physiol. 89B, 245-250.

Boldyrev, A.A., Stvolinsky, S.L., Tyulina, O.V., Koshelev, V.B., Hori, N., Carpenter, D.O., 1997. Biochemical and physiological evidence that carnosine is an endogenous neuroprotector against free radicals. Cell. Mol. Neurobiol. 17, 259-270.

Bondareff, W., Pysh, J.J., 1968. Distribution of the extracellular space during postnatal maturation of rat cerebral cortex. Anat. Rec. 160, 773-780.

Bonfanti, L., Theodosis, D.T., 1994. Expression of polysialylated neural cell adhesion molecule by proliferating cells in the subependymal layer of the adult rat, in its rostral extension and in the olfactory bulb. Neuroscience 62, 291-305.

Bonfanti, L., Poulain, D.A., Theodosis, D.T., 1993. Radial-glia-like cells in the supraoptic nucleus of the adult rat. J. Neuroendocr. 5, 1-5.

Bonfanti, L., Peretto, P., Merighi, A., Fasolo, A., 1997. Newly-generated cells from the rostral migratory stream in the accessory olfactory bulb of the adult rat. Neuroscience 81, 489-502.

Boulder, Committee, 1970. Embryonic vertebrate central nervous system: revised terminology. Anat. Rec. 166, 257-261.

Brown, C.E., 1981. Interactions among carnosine, anserine, ophidine and copper in biochemical adaptation. J. Theor. Biol. 88, 245-256.

Bruni, J.E., 1998. Ependymal development, proliferation, and functions. Microsc. Res. Tech. 41, 2-13.

Brunjes, P.C., Frazier, L.L., 1986. Maturation and plasticity in the olfactory system of vertebrates. Brain Res. Rev. 11, 1-45. 
Burd, G.D., Davis, B.J., Macrides, F., Grillo, M., Margolis, F.L., 1982. Carnosine in primary olfactory system: an autoradiographic and biochemical study. J. Neurosci. 2, 244-255.

Caggiano, M., Kauer, S., Hunter, D.D., 1994. Globose basal cells are neuronal progenitors in the olfactory epithelium: a lineage analysis using a replicationincompetent retrovirus. Neuron 13, 339-352.

Cairns, M.T., Miller, D.J., O'Dowd, J.J., 1988. Detection and estimation of carnosine, homocarnosine, $\mathrm{N}$-acetyl histidine and its 1-methyl derivative in rat brain by analytical HPLC. J. Physiol. 407, 51.

Caley, D.W., Maxwell, D.S., 1970. Development of the blood vessels and extracellular spaces during postnatal maturation of rat cerebral cortex. J. Comp. Neurol. 138, 31-48.

Calof, A.L., Mumm, J.S., Rim, P.C., Shou, J., 1998. The neuronal stem cell of the olfactory epithelium. J. Neurobiol. 36, 190-205.

Camoletto, P., Peretto, P., Bonfanti, L., Manceau, V., Sobel, A., Fasolo, A., 1997. The cytosolic phosphoprotein stathmin is expressed in the olfactory system of the adult rat. NeuroReport 8, 2825-2829.

Cheeseman, K.H., Slater, T.F., 1993. An introduction to free radical biochemistry. British Medical Bull. 49, 481-493.

Chrichton, C.A., Lamont, C., Miller, D.J., O'Dowd, J.J., 1988. Detection and estimation of carnosine, anserine and novel imidazoles in cardiac and skeletal muscle in several species by high performance liquid chromatography. J. Physiol. 398, 74.

Cochard, P., Paulin, D., 1984. Initial expression of neurofilaments and vimentin in the central and peripheral nervous system of the mouse embryo in vivo. J. Neurosci. 4, 2080-2094.

Crowe, M.J., Pixley, S.K., 1991. Monoclonal antibody to carnosine synthetase identifies a subpopulation of frog olfactory receptor neurons. Brain Res. 538, 147-151.

Crush, K.G., 1970. Carnosine and related substances in animal tissues. Comp. Biochem. Physiol. 34, 3-30.

Dahl, D., Rueger, D., Bignami, A., 1981. Vimentin, the 57,000 molecular weight protein of fibroblast filaments, is the major cytoscheletal component in immature glia. Eur. J. Cell Biol. 24, 191-196.

Dellmann, H.D., 1998. Structure of the subfornical organ: a review. Microsc. Res. Tech. 41, 85-97.

De Marchis, S., Melcangi, R.C., Modena, C., Cavaretta, I., Peretto, P., Agresti, C., Fasolo, A., 1997. Identification of the glial cell types containing carnosinerelated peptides in the rat brain. Neurosci. Lett. 237, 37-40.

de Vitry, F., Picart, R., Jacque, C., Tixier-Vidal, A., 1981. Glial fibrillary acidic protein. A cellular marker of tanycytes in the mouse hypothalamus. Dev. Neurosci. 4, 457-460.

Drescher, M.J., Drescher, D.G., 1991. N-acetylhistidine, glutamate, and betaalanine are concentrated in a receptor cell layer of the trout inner ear. J. Neurochem. 56, 658-664.

Dupin, A.M., Bemananozara, M., Stvolinskii, S.L., Boldyrev, A.A., Severin, S.E., 1987. Muscle dipeptides: natural inhibitors of lipid peroxidation. Biokhimiya 52, 782-787.

Enwonuwu, C.O., Worthington, B.S., 1974. Regional distribution of homocarnosine and other ninhydrin-positive substances in brains of malnourished monkeys. J. Neurochem. 22, 1045-1052.

Evans, P.H., 1993. Free radicals in brain metabolism and pathology. British 
Medical Bull. 49, 577-587.

Ferriero, D., Margolis, F.L., 1975. Denervation in the primary olfactory pathway of mice, II. Effect on carnosine and other amine compounds. Brain Res. 94, 75-86.

Fisher, D.E., Amend, J.F., Strumeyer, D.H., 1977. Anserine and carnosine in chicks (Gallus gallus), rat pups (Rattus rattus and ducklings (Anas plathyrhynchos): comparative ontogenetic observations. Comp. Biochem. Physiol. 56B, 367-370.

Flament-Durand, J., Brion, J.P., 1985. Tanycytes: morphology and functions: a review. Int. Rev. Cytol. 96, 121-155.

Flancbaum, L., Fitzpatrick, J.C., Brotman, D.N., Marcoux, A-M., Kasziba, E., Fisher, H., 1990. The presence and significance of carnosine in histaminecontaining tissues of several mammalian species. Agents and Actions 31, 190-196.

Fraga, C.G., Shigenaga, M.K., Park, J.W., Degan, P., Ames, B.N., 1990. Oxidative damage to DNA during aging: 8-hydroxy-2'-deoxyguanosine in rat organ DNA and urine. Proc. Natl. Acad. Sci. USA 87, 4533-4537.

Garcia-Verdugo, J.M., Doetsch, F., Wichterle, H., Lim, D.A., Alvarez-Buylla, A., 1998. Architecture and cell types of the adult subventricular zone: in search of the stem cells. J. Neurobiol. 36, 234-248.

Gonzalez-Estrada, M.T., Freeman, W.J., 1980. Effects of carnosine on olfactory bulb EEG, evoked potentials and DC potentials. Brain Res. 202, 373-386.

Gorham, J.D., Ziff, E.B., Baker, H., 1991. Differential spatial and temporal expression of two type III intermediate filament proteins in olfactory receptor neurons. Neuron 7, 485-497.

Granger, B.L., Lazarides, E., 1979. Desmin and vimentin coexist at the periphery of the myofibril Z disc. Cell 18, 1053-1063.

Graziadei, P.P.C., Monti-Graziadei, G.A., 1978. The olfactory system: a model for the study of neurogenesis and axon regeneration in mammals. In: Cotman, C.V. (Ed.), Neuronal plasticity. Raven Press, New York, pp. 131-153.

Gulewitsch, W., Amiradzibi, S., 1900. Ueber das carnosin, eine neue organische base des fleischextractes. Ber. Dtsch. Chem. Ges. 33, 1902-1903.

Harding, J.W., Margolis, F.L., 1976. Denervation in the primary olfactory pathway of mice. III. Effect of enzymes of carnosine metabolism. Brain Res. 110, 351-360.

Harding, J.W., O'Fallon, J.V., 1979. The subcellular distribution of carnosine, carnosine synthetase and carnosinase in mouse olfactory tissues. Brain Res. 173, 99-109.

Hinds, J.W., Hinds, P.L., 1976. Synapse formation in the mouse olfactory bulb: quantitative studies. J. Comp. Neurol. 169, 15-40.

Hipkiss, A.R., 1998. Carnosine, a protective, anti-ageing peptide? Int. J. Biochem. Cell Biol. 30, 863-868.

Hipkiss, A.R., Michaelis, J., Syrris, P., 1995. Non-enzymatic glycosylation of the dipeptide L-carnosine, a potential anti-protein crossinking agent. FEBS Lett. 371, 81-85.

Hipkiss, A.R., Preston, J.E., Himswoth, D.T.M., Worthigton, V.C., Abbot, N.J., 1997. Protective effects of carnosine against malondialdehyde-induced toxicity towards cultured rat brain endothelial cells. Neurosci. Lett. 238, 145138.

Hirsch, J.D., Grillo, M., Margolis, F.L., 1978. Ligand binding studies in the mouse olfactory bulb: identification and characterization of a $\mathrm{L}-[3 \mathrm{H}]$ carnosine binding site. Brain Res. 158, 407-422. 
Hirsch, J.D., Margolis, F.L., 1979. L-[3H]Carnosine binding in the olfactory bulb. II. Biochemical and biological studies. Brain Res. 174, 81-94.

Hoffmann, A.M., Bakardjiev, A., Bauer, K., 1996. Carnosine-synthesis in cultures of rat glial cells is restricted to oligodendrocytes and carnosine uptake to astrocytes. Neurosci. Lett. 215, 29-32.

Hornig, D., 1975. Distribution of ascorbic acid, metabolites and analogues in man and animals. Ann. N.Y. Acad. Sci. 258, 103-118.

Horinishi, H., Grillo, M., Margolis, F.L., 1978. Purification and characterization of carnosine synthetase from mouse olfactory bulbs. J. Neurochem. 31, 909919.

Imamura, H., 1939. Chemie der Schlangen. I. uber die N-haltigen extraktivstoffe der schlangenmuskeln. J. Biochem. Tokyo 30, 479-490.

Jackson, M.C., Lenney, J.F., 1996. The distribution of carnosine and related dipeptides in rat and human tissues. Inflamm. Res. 45, 132-135.

Jankovski, A., Sotelo, C., 1996. Subventricular zone-olfactory bulb migratory pathway in the adult mouse: cellular composition and specificity as determined by heterochronic and heterotopic transplantation. J. Comp. Neurol. 371, 376-396.

Kalyankar, G., Meister, A., 1959. Enzymatic synthesis of carnosine and related b-alanyl and g-aminobutyryl peptides. J. Biol. Chem. 234, 3210-3218.

Kanaki, K., Kawashima, S., Kashiwayanagi, M., Kurihara, K., 1997. Carnosineinduced inward currents in rat olfactory bulb neurons in cultured slices. Neurosci. Lett. 231, 167-170.

Kanazawa, A., Sano, I., 1967. A method of determination of homocarnosine and its distribution in mammalian tissues. J. Neurochem. 14, 211-214.

Kastritsis, C.H., McKarthy, K.D., 1993. Oligodendroglial lineage cells express neuroligand receptors. Glia 8, 106-113.

Kish, S.J., Perry, T.L., Hansen, S., 1979. Regional distribution of homocarnosine, homocarnosine-carnosine synthetase and homocarnosinase in the human brain. J. Neurochem. 32, 1629-1636.

Klatzo, I., 1967. Neuropathological aspects of brain edema. J. Neuropath. Exp. Neurol. 26, 1-14.

Klebanov, G.I., Teselkin, YuO, Babenkova, I.V., Lyubitsky, O.B., Rebrova, O.Yu, Boldyrev, A.A., Vladimirov, YuA, 1998. Effect of carnosine and its components on free-radical reactions. Membr. Cell Biol. 12, 89-99.

Kohen, R., Yamamoto, Y., Cundy, K.C., Ames, B.N., 1988. Antioxidant activity of carnosine, homocarnosine and anserine present in muscle and brain. Proc. Natl. Acad. Sci. USA 85, 3175-3179.

Kornbrust, D.J., Mavis, R.D., 1979. Relative susceptibility of microsomes from lung, heart, liver, kidney, brain and testes to lipid peroxidation: correlation with vitamin E content. Lipids 15, 315-322.

Lee, J.C., Bakay, L., 1966. Ultrastructural changes in the edematous central nervous system. Arch. Neurol. 14, 36.

Lenney, J.F., 1976. Specificity and distribution of mammalian carnosinase. Biochim. Biophys. Acta. 429, 214-219.

Lenney, J.F., Kan, S-C., Siu, K., Sugiyama, G.H., 1977. Homocarnosine-a hog kidney dipeptidase with a broader specificity than carnosinase. Archs Biochem. Biophys. 184, 257-266.

Lois, C., Alvarez-Buylla, A., 1994. Long-distance neuronal migration in the adult mammalian brain. Science 264, 1145-1148.

Lois, C., Garcia-Verdugo, J., Alvarez-Buylla, A., 1996. Chain migration of neuronal precursors. Science 271, 978-981. 
Luskin, M.B., 1993. Restricted proliferation and migration of postnatally generated neurons derived from the forebrain subventricular zone. Neuron $11,173-189$.

MacLeod, N.K., Straughan, D.W., 1979. Responses of olfactory bulb neurones to the dipeptide carnosine. Exp. Brain Res. 34, 183-188.

Margolis, F.L., 1972. A brain protein unique to the olfactory bulb. Proc. Natl. Acad. Sci. USA 69, 1221-1224.

Margolis, F.L., 1974. Carnosine in the primary olfactory pathway. Science 184, 909-911.

Margolis, F.L., 1978. Carnosine. Trends Neurosci. 1, 42-44.

Margolis, F.L., 1980. Carnosine: an olfactory neuropeptide. In: Baker, J.L., Smith, T. (Eds.), The Role of Peptides in Neuronal Function. Dekker, New York, pp. 545-572.

Margolis, F.L., Grillo, M., 1977. Axoplasmic transport of carnosine (b-alanil-Lhistidine. in the mouse olfactory pathway. Neurochem. Res. 2, 507-519.

Margolis, F.L., Grillo, M., 1984a. Carnosine, homocarnosine and anserine in vertebrate retinas. Neurochem. Int. 6, 207-209.

Margolis, F.L., Grillo, M., 1984b. Inherited differences in mouse kidney carnosinase activity. Biochem. Genet. 22, 441-451.

Margolis, F.L., Grillo, M., Grannot-Reisfeld, N., Farbman, A.I., 1983. Purification, characterization and immunocytochemical localization of mouse kidney carnosinase. Biochim. Biophys. Acta. 744, 237-248.

Margolis, F.L., Grillo, M., Kawano, T., Farbman, A.I., 1985. Carnosine synthesis in olfactory tissue during ontogeny: effect of exogenous b-alanine. J. Neurochem. 44, 1459-1464.

Margolis, F.L., Grillo, M., Hempstead, J., Morgan, J.I., 1987. Monoclonal antibodies to mammalian carnosine synthetase. J. Neurochem. 48, 593-600.

McFarland, G.A., Holliday, R., 1994. Retardation of senescence of cultured human diploid fibroblasts by carnosine. Exp. Cell Res. 212, 167-175.

Menezes, J.R.L., Luskin, M.B., 1994. Expression of neuronspecific tubulin defines a novel population in the proliferative layers of the developing telencephalon. J. Neurosci. 14, 5399-5416.

Mroz, E.A., Sewell, W.F., 1989. Pharmacological alterations of the activity of afferent fibers innervating hair cells. Hear. Res.38, 141-162.

Munch, G., Thome, J., Foley, P., Schinzel, R., Riederer, P., 1997. Advanced glycation endproducts in ageing and Alzheimer's disease. Brain Res. Rev. 23, 134-143.

Nadi, N.S., Margolis, F.L., 1978. A simple method for the elimination of amine contaminants in buffers for single column amino acid analysis in physiological samples at picomole levels. Analyt. Biochem. 91, 180-185.

Nadi, N.S., Hirsch, J.D., Margolis, F.L., 1980. Laminar distribution of putative neurotransmitter aminoacids and ligand binding sites in the dog olfactory bulb. J. Neurochem. 34, 138-146.

Neidle, A., Kandera, J., 1974. CarnosineĐan olfactory bulb peptide. Brain Res. 80, 359-364.

Nicholls, D., Attwell, D., 1990. The release and uptake of excitatory amino acids. Trends Pharmacol. Sci. 11, 462-468.

Nicoll, R.A., Alger, B.E., Jahr, C.E., 1980. Peptides as putative excitatory neurotransmitters: carnosine, enkephalin substance $P$ and TRH. Proc. R. Soc. Lond. (B) 210, 133-149.

Nielsen, S., Nagelhus, E.A., Amiry-Moghaddam, M., Bourque, C., Agre, P., Ottersen, O.P., 1997. Specialized membrane domains for water transport in 
glial cells: high resolution immunogold cytochemistry of aquaporin-4 in rat brain. J. Neurosci. 17, 171-180.

Ng, R.H., Marshall, F.O., 1978. Regional and subcellular distribution of homocarnosine-carnosine synthetase in the central nervous system of rats. J. Neurochem. 30, 187-190.

Ng, R.H., Marshall, F.O., Henn, F.A., Sellstrom, A., 1977. Metabolism of carnosine and homocarnosine subcellular fractions and neuronal and glial cell-enriched fractions of rabbit brain. J. Neurochem. 28, 449-452.

O'Dowd, J.J., Cairns, M.T., Robins, D.J., Miller, D.J., 1990. Analysis of carnosine, homocarnosine, and other histidyl derivatives in rat brain. J. Neurochem. 55, 446-452.

Panzanelli, P., Valli, P., Cantino, D., Fasolo, A., 1994. Glutamate and carnosine in the vestibular system of the frog. Brain Res. 662, 293-296.

Panzanelli, P., Cantino, D., SassoeÁ-Pognetto, M., 1997. Colocalization of carnosine and glutamate in photoreceptors and bipolar cells of the frog retina. Brain Res. 758, 143-152.

Pavlov, A.R., Revina, A.A., Dupin, A.M., Boldyrev, A.A., Yaropolov, A.I., 1993. The mechanism of interaction of carnosine with superoxide radicals in water solutions. Biochim. Biophys. Acta. 1157, 304-312.

Peretto, P., Merighi, A., Fasolo, A., Bonfanti, L., 1997. Glial tubes in the rostral migratory stream of the adult rat. Brain Res. Bull. 42, 9-21.

Peretto, P., Bonfanti, L., Merighi, A., Fasolo, A., 1998. Carnosine-like immunoreactivity in astrocytes of the glial tubes and in newly-generated cells within the tangential part of the rostral migratory stream of rodents. Neuroscience 85, 527-542.

Peretto, P., Merighi, A., Fasolo, A., Bonfanti, L., 1999 The subependymal layer in rodents: a site of structural plasticity and cell migration in the adult mammalian brain, Brain Res. Bull. 49, in press.

Pisano, J.J., Wilson, J.D., Cohen, L., Abraham, D., Udenfriend, J., 1961. Isolation of g-aminobutyrylhistidine (homocarnosine from brain. J. Biol. Chem. 236, 499-502.

Pixley, S.K.R., De Vellis, J., 1984. Transition between immature radial glia and mature astrocytes studied with a monoclonal antibody to vimentin. Dev. Brain Res. 15, 201-209.

Pocchiari, F., Tentori, L., Vivaldi, G., 1962. The presence of the dipeptide balanyl-3-methylhistidine in whale meat extract. Scient. Rep. Ist. Super. SanitaÁ 2, 188-194.

Preston, J.E., Hipkiss, A.R., Himsworth, D.T.M., Romero, I.A., Abbot, N.J., 1998. Toxic effects of b-amyloid(25-35) on immortalised rat brain endothelial cell: protection by carnosine, homocarnosine and b-alanine. Neurosci. Lett. 242, 105-108.

Quinn, M.R., Fisher, H., 1977. Effect of dietary histidine deprivation in two rat strains on hemoglobin and tissue concentrations of histidine-containing dipeptides. J. Nutrition 107, 2044-2054.

Quinn, P.J., Boldyrev, A.A., Formazuyk, V.E., 1992. Carnosine: its properties, functions and potential therapeutic applications. Molec. Aspects Med. 13, 379-444.

Rochel, S., Margolis, F.L., 1982. Carnosine release from olfactory bulb synaptosomes is calcium-dependent and depolarization-stimulated. J. Neurochem. 38, 1505-1514.

Rosemberg, A., 1960. Purification and some properties of carnosinase of swine kidney. Archs. Biochem. Biophys. 88, 83-93. 
Rousselot, P., Lois, C., Alvarez-Buylla, A., 1995. Embryonic (PSA) N-CAM reveals chains of migrating neuroblasts between the lateral ventricle and the olfactory bulb of adult mice. J. Comp. Neurol. 351, 51-61.

Sakai, M., Yoshida, M., Karasawa, N., Teramura, M., Ueda, H., Nagatsu, I., 1987. Carnosine-like immunoreactivity in the primary olfactory neuron of the rat. Experientia 43, 298-300.

Sakai, M., Kani, K., Karasawa, N., Yoshida, M., Nagatsu, I., 1988. Carnosine-like immunoreactivity in the olfactory bulb of the rat: an electron microscopic study. Brain Res. 438, 335-338.

Sakai, M., Ashihara, M., Nishimura, T., Nagatsu, I., 1990. Carnosine-like immunoreactivity in human olfactory mucosa. Acta Otolaryngol. (Stockh) $109,450-453$.

Salim-Hanna, M., Lissi, E., Videla, L.A., 1991. Free radical scavenging activity of carnosine. Free Rad. Res. Comms. 14, 263-270.

Sano, I., 1965. Simple peptides in brain. Int. Rev. Neurobiol. 12, 235-263.

Sassoè-Pognetto, M., Cantino, D., Fasolo, A., 1992. Carnosine-like immunoreactivity is associated with synaptic vesicles in photoreceptors of the frog retina. Brain Res. 578, 261-268.

Sassoè-Pognetto, M., Cantino, D., Panzanelli, P., Verdun di Cantogno, L., Giustetto, M., Margolis, F.M., De Biasi, S., Fasolo, A., 1993. Presynaptic colocalization of carnosine and glutamate in olfactory neurons. NeuroReport 5, 7-10.

Schulz, M., Hamprecht, B., Kleinkauf, H., Bauer, K., 1987. Peptide uptake by astroglia-rich brain cultures. J. Neurochem. 49, 748-755.

Schwob, J.E., Gottlieb, D.I., 1986. The primary olfactory projection has two chemically distinct zones. J. Neurosci. 6, 3393-3404.

Schwob, J.E., Faber, N.B., Gottlieb, D.I., 1986. Neurons of the olfactory epithelium in adult rats contain vimentin. J. Neurosci. 6, 208-217.

Scriver, C.R., Nutzenadel, W., Perry, T.L., 1983. Disorders of $\mu$-alanine and carnosine metabolism. In: Stambury, J.B., Wyngaarden, J.B., Goldstein, J.L., Brown, M.S. (Eds.), The metabolic basis of inherited disease. McGraw-Hill, New York, pp. 528-542.

Shaw, G., Osborn, M., Weber, K., 1981. An immunofluorescence microscopical study of the neurofilament triplet proteins, vimentin and glial fibrillary acidic protein within the adult rat brain. Eur. J. Cell Biol. 26, 68-82.

Shilton, B.H., Walton, D.J., 1991. Sites of glycation of human and horse liver alcohol dehydrogenase in vivo. J. Biol. Chem. 266, 5587-5592.

Skaper, S.D., Das, S., Marshall, F.D., 1973. Some properties of a homocarnosine-carnosine synthetase isolated from rat brain. J. Neurochem. $21,1429-1445$.

Skulachev, V.P., 1978. Membrane-linked energy buffering as the biological function of $\mathrm{Na}+/ \mathrm{K}+$ gradient. FEBS Lett. 87, 171-179.

Slivka, A., Mytilineou, C., Cohen, G., 1987. Histochemical evaluation of glutathione in brain. Brain Res. 409, 275-284.

Smart, I., 1961. The subependymal layer of the mouse brain and its cell production as shown by radioautography after thymidine-H3 injection. J. Comp. Neurol. 116, 325-338.

Smith, M.A., Sayre, L.M., Monnier, V.M., Perry, G., 1995. Radical AGEing in Alzheimer's disease. Trends Neurosci. 18, 172-176.

Sri-Kantha, S., Wada, S., Tanaka, H., Takeuchi, M., Watabe, S., Ochi, H., 1996. Carnosine sustains the retention of cell morphology in continuous fibroblast 
culture subjected to nutritional insult. Biochem. Biophys. Res. Comm. 223, 278-282.

Steinert, P.M., Roop, D.R., 1988. Molecular and cellular biology of intermediate filaments. Annu. Rev. Biochem. 57, 593-625.

Tamaki, N., lizumi, H., Masumitu, N., Kubota, A., Hama, T., 1976. Species specificity on the contents of anserine and carnosine. Yakugaku Zasshi 96, 1481-1486.

Theodosis, D.T., Poulain, D.A., 1993. Activity-dependent neuronal-glial and synaptic plasticity in the adult mammalian hypothalamus. Neurosci. 57, 501535.

Tsunoo, S., Horisaka, K., Kawasumi, M., Aso, K., Tokue, S., 1963a. The free aminoacids in chicken brain. The isolation and identification of histidine and anserine. J. Biochem. Tokyo 54, 355-362.

Tsunoo, S., Horisaka, K., Sasaki, S., Aso, K., Tokue, S., 1963b. The free aminoacids in chicken eyes. The isolation and identification of histidine and anserine. J. Biochem. Tokyo 54, 363-368.

Vladimirov, Y.V., Archakov, A.I., 1972. In: Lipid peroxidation in biological membranes, . Nauka Publishers, Moscow, p. 252.

Wagner, H-J., Pilgrim, C., 1974. Extracellular and transcellular transport of horseradish peroxidase (HRP) through the hypothalamic tanycyte ependyma. Cell Tiss. Res. 152, 477-491.

Weiss, S., Reynolds, B.A., Vescovi, A.L., Morshead, C., Craig, C.G., van der Kooy, D., 1996. Is there a neural stem cell in the mammalian forebrain? Trends Neurosci. 19, 387-393.

Wichterle, H., Garcia-Verdugo, J.M., Alvarez-Buylla, A., 1997. Direct evidence for homotypic, glia-independent neuronal migration. Neuron 18, 779-791.

Wideman, J., Brink, L., Stein, S., 1978. New automated fluorometric peptide microassay for carnosine in mouse olfactory bulb. Analyt. Biochem. 86, 670678.

Winnick, R.E., Winnick, T., 1959. Carnosine-anserine synthetase of muscle. Biochim. Biophys. Acta. 31, 47-55.

Yockey, W.C., Marshall, F.D., 1969. Incorporation of [14C]histidine into homocarnosine and carnosine of frog brain in vivo and in vitro. Biochem. J. $114,585-588$. 